\begin{tabular}{|c|l|}
\hline Title & $\begin{array}{l}\text { Depositional chronology and fabric of Siwalik group sediments in Central Nepal from magnetostratigraphy and } \\
\text { magnetic ani sotropy }\end{array}$ \\
\hline Author(s) & Gautam, Pitambar; Rösler, Wolfgang \\
\hline Citation & $\begin{array}{l}\text { Journal of A sian Earth Sciences, 17(5-6), 659-682 } \\
\text { https://doi.org/10.1016/S1367-9120(99)00021-8 }\end{array}$ \\
\hline Issue Date & $1999-10$ \\
\hline Doc URL & http:/hdl.handle.net/2115/42496 \\
\hline Type & article (author version) \\
\hline File Information & siwmgnp-rv-99.pdf \\
\hline
\end{tabular}

Instructions for use 
Final Manuscript of paper published in

Journal of Asian Earth Sciences, vol. 17, issue 5-6 (1999), pp. 659-682

\title{
Depositional Chronology and Fabric of Siwalik Group Sediments in Central Nepal From Magnetostratigraphy and Magnetic Anisotropy
}

\author{
Pitambar Gautam $^{1}$ and Wolfgang Rösler ${ }^{2}$ \\ 1 Department of Earth and Planetary Sciences, Graduate School of Science, Hokkaido University, \\ N10 W8, Sapporo 060-0810, Japan \\ (On leave from: Central Department of Geology, Tribhuvan University, Kirtipur, Kathmandu, Nepal) \\ 2 Institut für Geologie und Paläontologie, Universität Tübingen, \\ Sigwartstrasse 10, 72076 Tübingen, Germany
}

\begin{abstract}
Magnetostratigraphic research, undertaken within the past 15 years in the Siwaliks distributed along $400 \mathrm{~km}$ of the Sub-Himalaya in central Nepal, has proved that the sediments possess highly reliable hematite-based primary detrital remanent magnetization suitable to determine depositional chronology. In order to bring out the polarity sequences in a common chronological frame, all available data are newly correlated to the latest global magnetic polarity time scale of Cande and Kent (1995). Chronological data presented are referred in relation to the diverse lithological nomenclature to the formations whose ages are not constrained by isotopic or paleontologic ages. The age of the sections dated by magnetostratigraphy ranges between 14 and <2 Ma. Sediment accumulation rates average to $32-50 \mathrm{~cm} \mathrm{kyr}^{-1}$. Rock-magnetic parameters, e.g. initial susceptibility and isothermal remanent magnetization ratios, allow correlation with an accuracy of up to a few hundred meters among several kilometers thick adjacent sections.

Anisotropy of magnetic susceptibility (AMS) data reveal a well-defined fabric contributed by paramagnetic $\left(\mathrm{k}=10^{-5}\right.$ to $\left.3 \times 10^{-4} \mathrm{SI}\right)$ as well as ferromagnetic minerals $(\mathrm{k}=$ $3 \times 10^{-4}$ to $10^{-2} \mathrm{SI}$ ). AMS ellipsoids are mainly oblate along with prolate ones and the degree of anisotropy is mostly low $\left(\mathrm{P}^{\prime}<1.2\right)$. The magnetic fabric is of pre-folding origin with tiltcorrected sub-vertical magnetic foliation poles. The magnetic lineations do not show parallelism to the expected paleocurrent directions. Rather, sub-parallelism between the clusters of magnetic lineation and the fold axes/bedding strikes/thrust fronts is observed. A superimposed fabric consisting of a sedimentary-compactional and an overprint induced by mild deformation process is suggested. The latter process was active during and subsequent to the deposition in the compressive tectonic setting of the foreland basin. The magnetic lineations for Tinau Khola and Surai Khola sections cluster around $\mathrm{N} 80^{\circ} \mathrm{W}$ and $\mathrm{N} 88^{\circ} \mathrm{W}$ respectively, whereas $\mathrm{N} 27^{\circ} \mathrm{W}$ trend characterizes the Amiliya-Tui area south of Dang. The peak clusters in lineations are probably orthogonal to the true shortening axes. Their variation along the Sub-Himalaya, together with the fold axes or thrust front trends, may be used for accurate tectonic reconstruction. It is especially important when orthogonality of the latter to the shortening axes may not hold true in the sectors with imbricate fold-and-thrust structures.
\end{abstract}

Key words: magnetic polarity stratigraphy, geomagnetic polarity time scale, Himalaya, Siwaliks, magnetostratigraphy, anisotropy of magnetic susceptibility (AMS), hematite, goethite, compressional setting, Nepal, paleomagnetism 


\section{Introduction}

The Siwalik Group comprises fluvial sediments deposited into the foredeep developed along the southern margin of the Himalayan mountain range, which underwent successive uplift, in response to the mountain building process accompanied by continued northward motion of the Indian plate after the India-Eurasia collision, and subsequent erosion. These sediments are exposed in the narrow Sub-Himalayan belt stretching for over $2000 \mathrm{~km}$ from Potwar Plateau in the west to the eastern syntaxial bend in Arunachal, India. They represent a natural record of time-dependent variations in lithology being supplied by rivers flowing from the main Himalayan hinterland in the north, together with faunal, floral and palynological features that characterized the depositional basin and also the past climatic history of the entire Himalayan region.

The earliest lithological and paleontological observations of the Siwaliks were made in the western Sub-Himalaya where a tripartite subdivision based on lithology and six-fold faunal zone nomenclature, covering an age between Middle Miocene and Early Pleistocene, have been developed (Pilgrim, 1913; Auden, 1935; Gill, 1951; Wadia, 1957 and others). For Potwar Plateau, the faunal zones (corresponding lithofacies) are Kamlial and Chinji (Lower Siwaliks), Nagri and Dhok Pathan (Middle Siwaliks), and Tatrot and Pinjore (Upper Siwaliks). Though the Siwalik fossil assemblages in individual sections show strong similarity in time and allow correlation accuracy of a few myrs (Flynn et al., 1990: the minimum estimate for the longevity of rodent species is $1.8 \mathrm{myr}$ ), their occurrence in exposed individual sections is either non-uniform or simply inadequate even in the western Sub-Himalaya. Besides, the use of lithological markers for correlating fluviatile sections is questionable. Towards the end of the seventies, with the development of magnetostratigraphy as a dating tool, the Siwalik Group lithofacies were found to record accurately the successive polarities of the geomagnetic field which occurred during deposition times (Keller et al., 1977; Barndt et al., 1978; and Opdyke et al., 1979). Extensive magnetostratigraphic work aimed at obtaining such records from the sedimentary sequences and dating was then followed in Pakistan and India (see N.M. Johnson et al., 1982; Tauxe and Opdyke, 1982; Opdyke, 1990 for a review; and Butler, 1992 for a brief summary). The isotopic ages determined from the volcanic ashes supplied by volcanoes in nearby Afghanistan and preserved at several levels served as reference points for correlating the polarity patterns with the geomagnetic polarity time scale (GPTS) (G.D. Johnson et al., 1982). Thanks to these efforts, the Potwar plateau now has a firm chronostratigraphy established through the combination of magnetostratigraphy, isotopic dating, and partially revised biostratigraphic zonation (Opdyke et al., 1979; Barry et al., 1982; Johnson et al., 1983; and Flynn et al., 1990).

During the early stages of the Siwalik research in Nepal, the tripartite lithostratigraphic divisions (Lower, Middle and Upper Siwaliks) were commonly adapted (e.g., Auden, 1935; Lombard, 1958; Hagen, 1969; Itihara et al., 1972; Yoshida and Arita, 1982; DMG, 1987) and additionally attempts to use other criteria such as sandstone petrography or heavy mineral assemblage to aid lithostratigraphic recognition were also made (Chaudhri and Gill, 1981 and Chaudhri, 1982). Chronology of the sediments remained largely unknown because of the absence of either paleontological (no index fossils with narrow time range) or isotopic age (no datable volcanic ashes probably due to remote location of the typical volcanic sources in Afghanistan) data. Further recognition that the Sub-Himalayan basin has an accretionary prism-like structure, characterized by a package of 
multiple, several to a few tens of kilometers wide, deformed slices bounded by series of thrusts resulting from continuous slightly oblique convergence, revealed its true complexity (Herail et al., 1986; Le Fort, 1989 and Mugnier et al., 1992).

A study of the polarity record in the Tinau Khola section in an attempt to date the horizon yielding Sivapithecus punjabicus by Munthe et al. (1983) marks the beginning of the magnetostratigraphic research in the Nepalese Siwaliks. The next generous effort was made by M. Yoshida in Arung Khola-Binai Khola where over 12 sections distributed over an area of $5,000 \mathrm{~km}^{2}$ were measured for the polarity record and the finer lithostratigraphic divisions were dated using magnetostratigraphy (Tokuoka et al., 1986). With the development of cryogenic magnetometers and sophisticated laboratory procedures capable of extracting the weak primary magnetization, relatively continuous sequences of the Nepalese Siwaliks have been important targets for the world's paleomagnetic community (Appel et al., 1991; Harrison et al., 1993; Gautam and Appel, 1994; and Rösler et al., 1997).

This paper is a summary of the currently existing magnetostratigraphic and magnetic fabric data from central Nepal. For chronological correlation, the data are described areawise: Surai Khola - Amiliya-Tui (SK-AT) in the west, Arung Khola-Tinau Khola (AK-TK) in the center, and Bakiya Khola (BK) and Rato Khola (RK) in the east (Fig. 1). Owing to the yet sparse nature of the anisotropy of magnetic susceptibility (AMS) data, they are presented collectively for the Amiliya-Tui, Surai Khola, Tinau Khola and Rato Khola sections.

Magnetostratigraphic research of fluvial sediments has passed through some changes that occurred during the past two decades. These are: preference to sandstone or siltstone over clay; use of cryogenic or new-generation spinner magnetometers having 10-100 times higher sensitivity than those used earlier; application of stepwise thermal instead of alternating field demagnetization; and the frequent revisions in the standard GPTS. So, one of the main objectives of this paper is to re-evaluate and compile the various data accumulated on the Nepalese Siwaliks and to correlate all the polarity sequences to the latest reference polarity scale by Cande and Kent (1995).

\section{Geological Setting}

The Siwalik Group in Nepal comprises c. $6000 \mathrm{~m}$ thick, generally coarsening and thickening upwards sedimentary megacycle, built up by numerous fining upward sediment cycles of sandstones to clays produced by a fluvial system. Based on lithologies, reflecting the depositional environment, the following classical divisions may be applied:

i) Lower Siwaliks (LS)- alternations of fine- to medium-grained gray sandstones and variegated or gray mudstones forming nearly uniform sedimentary cycles with a thickness of a few meters. They indicate a calm floodplain environment;

ii) Middle Siwaliks (MS)- medium- to coarse- grained, gray, mica-rich "salt \& pepper" sandstones, often several tens of meters thick, with sparsely intercalated mudstones. They form cuesta-type topographic features. Their deposition is attributed to a braided river system; and,

iii) Upper Siwaliks (US) - pebble and cobble conglomerates often tens of meters in thickness, with intercalations of loose sandstones and clay layers. They were possibly formed as alluvial fan deposits near the mountain front.

Many geologists, however, claim such a tripartite division to be inadequate for detailed mapping. Lithological variability, the lack of biostratigraphic markers, the varying degree of tectonic dissection resulting in package of multiple slices of thrusts are quoted as some of the most obvious reasons. Three lithostratigraphic nomenclature schemes prevailing 
in central Nepal are summarized in Fig. 2. Tokuoka et al. (1986) emphasized the particle size (mudstone, sandstone, and conglomerate) and more importantly the relative proportion of the sandstone and mudstone combined with the color variability of mudstone beds. This scheme was subsequently extended to Tinau Khola by the same team (see Tokuoka et al., 1990). Sah et al. (1994) and Ulak and Nakayama (1998) preferred to use another nomenclature for the Hetauda-Bakiya Khola area despite the use of criteria similar to those of Tokuoka's team.

Five or six lithostratigraphic divisions proposed earlier (Corvinus, 1993; Corvinus and Nanda, 1994) for the Surai Khola traverse were retained by Dhital et al. (1995) for the whole Siwalik belt around the Surai Khola. According to Dhital et al. (1995), the lithological or fossil-based criteria developed in the eastern part are not suitable in their area, where emphasis had to be given to the grain size, bed thickness, sedimentary structures, and also to the proportion of detrital mica, quartz, and feldspar in sandstones.

For several sections in the west (Amiliya-Tui, Arjun Khola, Bhalubang, and Rato Khola sections), however, the classical nomenclature remains (Greiner, 1992; Boving, 1992; and Metzler, 1993). For the sake of uniformity, even the Surai Khola section was labelled in this fashion in Rösler et al. (1997). Because of diachronous nature of even the identical lithostratigraphic boundaries found in different sections, proliferation of nomenclature has little meaning in chronological sense. Moreover, the chronology of deposition derived from magnetic polarity record of continuous section through its correlation to the GPTS is related to thickness level alone and is unaffected by the lithostratigraphic nomenclature adapted. For this reason, no attempt is made in this paper to change the existing (singular or even multiple for the same section) nomenclature schemes.

\section{Magnetic Polarity Stratigraphy}

The primary objective of a magnetostratigraphic study is to provide an age estimate for an event (or series of events) occurring within a sedimentary sequence. The first stage in doing this is to accurately decipher the polarity (sequence) of a rock (succession) at the time of its deposition. To determine the date, this polarity (sequence) has to be correlated to an absolute time scale. Correlation is commonly performed taking into account other available stratigraphic information (e.g., biostratigraphic) and radioisotopic dates. Because of the random spacing of the polarity reversals with respect to geologic time, recurrence of patterns of successive polarity intervals cannot be expected. Therefore, the common approach is to look for "fingerprints" (patterns of long and short intervals of differing polarity) unique to particular intervals of geologic time preserved in relatively long well determined polarity sequences. Correlation of such "fingerprints" to the patterns of a standard GPTS forms the basis of magnetostratigraphic dating.

\section{Geomagnetic polarity time scales - a review}

The development of the GPTS began in the 1960s as a result of time series analysis of the magnetic polarity (normal or reverse) of Pliocene-Pleistocene igneous rocks collected from widely separated localities and the ages assigned by potassium-argon (K-Ar) dating. Igneous rocks of the same age were commonly found to have the same polarity irrespective of global location. The compilation of the age and polarity data led to the development of the first GPTSs in the 0-5 Ma time interval (for details, see Cox, 1973 and Hailwood, 1989). These scales have "event" and "epoch" nomenclature. Polarity epochs, named after prominent figures (e.g. Gilbert) in the history of geomagnetism, are relatively long intervals of either normal or reverse polarity, identified during the early stages of the GPTS development, and thought of roughly about 1 myr duration. Polarity events are shorter 
intervals of opposite polarity occurring within polarity epochs. A particular event is named after the locality (e.g., Jaramillo) it was first discovered.

The discovery of marine magnetic anomalies, arranged symmetrically across and sub parallel to the mid-ocean ridges and having alternating polarity, formed the basis of the 'sea floor spreading' hypothesis (Vine and Matthews, 1963), which became a fundamental observation in development of plate tectonic theory. These anomalies indicated that the Earth's magnetic field had reversed its polarity at irregular intervals in the past. The analysis of observed magnetic anomaly pattern from a few South Atlantic profiles, under an assumption of constant spreading rate, led to the construction of the first detailed GPTS for the Late Cretaceous to Recent times by Heirtzler et al. (1968) (HDHPL68, for acronyms here after see Fig. 3).

With the addition of more details on seafloor anomalies from the South Atlantic, further improvements in dating methods, determination of new radiometric decay constants and use of additional control points for chronometrical calibration with time, constant revisions were made resulting in a series of important scales such as GTS82, GTS89 and BKFV85. A completely new compilation of relative anomaly spacings making use of worldwide marine magnetic profiles resulted in CK92 by Cande and Kent (1992). On the other hand, astronomically calibrated time scales, which rely on the record of Milankovitch climatic cycles in the lithology of marine sediments, have been worked out for the Pliocene and Pleistocene (see Hilgen, 1991a). The astronomically calibrated time scales have assigned ages systematically older than in CK92 but consistent with the refined radioisotopic dating methods (Renne et al., 1994; Berggren et al., 1985). CK95, the latest version by Cande and Kent (1995) takes into account these discrepancies and brings the chron boundaries in line with the existing astronomic calibrations.

It will be worthwhile to note that for ages younger than $5.23 \mathrm{Ma}$, the very detailed relative anomaly spacings elaborated in CK92 were not recalibrated in CK95; rather the ages were simply replaced by the astronomically calibrated time scale of Hilgen (1991b). In some parts of CK95, where the magnetic record of the sediments, which are used for astronomical calibration, is poorly defined, the improvements using astronomical calibration can be questioned. For example, chron C2r.1n of 32 kyrs duration (2.197 - 2.229 Ma) in CK92 has been reduced to $10 \mathrm{kyrs}(2.140-2.150 \mathrm{Ma})$ in CK95. One notable feature is that the polarity patterns in different versions of GPTSs are quite similar from GTS82 onwards (Fig. 4). A time resolution on the order of $10^{4} \mathrm{yrs}$ with respect to the polarity pattern is possible for all modern GPTSs (GTS82 through CK95). Though CK95 has been taken as standard during our compilation, changes in absolute age by improved calibration methods and the invention of new calibration points are still possible such that boundaries of certain polarity intervals may in future be shifted in absolute age.

The latest nomenclature system used in GPTS consists of chrons, subchrons and cryptochrons (see designation attached to CK95 in Fig. 3). A chron is a long interval of predominantly one polarity denoted by a number given to the corresponding marine magnetic anomaly and followed by the suffix $\mathrm{n}$ for normal polarity, or $\mathrm{r}$ for the preceding reversed polarity interval. For example, C5n and C5r are the normal and reverse polarity chrons corresponding to anomaly 5 . Intervals of shorter polarity occurring within a chron are called subchrons. The subchrons are identified by appending, from youngest to oldest, a $0.1,0.2$ etc., to the primary chron name, and adding an $\mathrm{n}$ for a normal polarity interval, or an $\mathrm{r}$ for a reversed interval. For example, C5n.1n and C5n.2n are subchrons of normal polarity contained within chron C5n. Similarly, C5n.1r and C5n.2 are subchrons of reverse polarity preceding C5n.1n and C5n.2n, respectively. Very short polarity intervals corresponding to tiny wiggles with a duration of less than $30 \mathrm{kyr}$ are called cryptochrons, which are designated 
as $-1,-2$ etc. following the primary chron or subchron designation. For example, the tiny wiggles within anomaly $5 \mathrm{n}$ are called, from youngest to oldest, cryptochrons C5n.2n-1, C5n.2n-2 and C5n.2n-3.

\section{Dependence of the inferred sediment accumulation rates on the GPTS}

The revisions in GPTS have resulted in variations in sediment accumulation rate (SAR) estimates reported at various times. This is especially true for short time spans whose relative durations changed significantly. To have a better insight on these changes, we calculated the 'relative chron duration factor' defined here as the ratio of $\Delta \mathrm{t}{ }_{\mathrm{CK} 95}$ (the duration of a particular magnetic polarity interval in $\mathrm{CK}_{95}$ ) to $\Delta \mathrm{t}$ TS (the duration of correlated polarity interval in other global polarity time scale in question, i.e. one of the scales from GTS82, GTS89, BKFV85 and CK92). This factor has been plotted against the absolute time in Fig. 4. For all time scales C5Bn falls close to $15 \mathrm{Ma}$. The present-day serves as a second fixed reference point. The sequence from $\mathrm{C} 5 \mathrm{Bn}$ to $\mathrm{C} 5 \mathrm{n}$ is characterized by small amplitude changes of relative chron durations for all displayed time scales. The pre-CK92 GPTSs show a systematic trend towards lower values around 0.8 , along with younger absolute ages in the middle part of the displayed sequence. This also results in generally higher values for the time younger than $\mathrm{C} 5 \mathrm{n}$ until about $\mathrm{C} 3 \mathrm{n} .4 \mathrm{n}(\mathrm{o})$. For ages younger than $\mathrm{C} 3 \mathrm{n} .4 \mathrm{n}(\mathrm{o})(5.23 \mathrm{Ma}$ in CK95), all time scales except CK95 show similar changes of moderate amplitudes. Between C5n and C3n.4n(o), frequent and irregular changes in the relative anomaly spacing for the investigated time scales are seen pointing to multiple revisions in the anomaly pattern.

Assuming that the CK95 time is "correct", the curves in Fig. 4 give a measure of how the magnetic pattern of previous GPTSs was distorted. Sediment accumulation rates (SARs) determined for sections of a measured thickness $(\Delta d)$, correlated with magnetic intervals with durations of $\Delta \mathrm{t}$ may be recalculated according to the following equation:

$$
\frac{S A R_{T S}}{S A R_{C K 95}}=\frac{\Delta d}{\Delta t_{T S}} \cdot \frac{\Delta t_{C K 95}}{\Delta d}=\frac{\Delta t_{C K 95}}{\Delta t_{T S}}
$$

It is evident from Fig. 4 that SARs depend on the GPTS adapted for correlation. The SARs calculated earlier for the past 11 and $7 \mathrm{Ma}$ period were probably overestimated. Multiple highs and lows in SARs might have caused incorrect assumptions of several accelerated uplift/erosion episodes of the Himalaya. For example, SARs for the long normal chron 5n (approx. 9-10.3 Ma), interval based on correlation with BKFV85 or GTS89 would be underestimated by about $20 \%$ than the rates derived using CK92 or CK95.

\section{Sampling interval}

The polarity of the geomagnetic field has reversed about 4 times per myr during the Neogene (Butler, 1992). Assuming the average SAR for Nepalese Siwaliks to be $40 \mathrm{~cm} . \mathrm{kyr}^{-1}$, the expected thickness of a typical polarity zone would be $100 \mathrm{~m}$. Therefore, sampling sites/levels spaced $30 \mathrm{~m}$ apart along thickness column should generally allow polarity zonation (3 points within an interval). However, as the SARs in Siwaliks vary with age, a denser (rarer) spacing for lower (upper) parts may be appropriate. Furthermore, assuming that a minimum of 10 polarity zones in succession will be enough for recognition of polarity "fingerprints", the minimum thickness would be about $1000 \mathrm{~m}$. In short, in order to get sufficient resolution, the minimum time span for a Siwalik section would be 2.5 myrs and the average sampling interval on the order of $30 \mathrm{~m}$ may be sufficient if a large percentage of sampled levels provide unambiguous polarity determination. 


\section{Magnetic Remanence and Some Rock Magnetic Characteristics}

Depositional remanent magnetization in sediments

The natural remanent magnetization (NRM) preserved in a fluvial sediment is a resultant of remanences of detrital (depositional or post-depositional), chemical and viscous origin. Physical alignment of ferromagnetic grains by the ambient aligning magnetic force (leading to a state where the sum of particle moments and the magnetic field are parallel), action of gravitational torques causing rotation of the non-uniformly shaped grains towards the horizontal, and alignments by hydrodynamic forces all acting at the time of deposition contribute to the depositional remanent magnetization (DRM). It has been shown by experiments that the DRM recorded by oblate hematite grains gives rise to inclination flattening and also to relatively large scatters in the recorded declinations (King, 1955; Tauxe and Kent, 1984). The observed inclination (Io) and the inclination of the ambient magnetic field $\left(I_{a}\right)$ satisfy the relationship: $\tan (I o)=f \times \tan \left(I_{a}\right)$, where $\mathrm{f}$ typically lies between 0.4 and 0.6.

Physical alignment processes that occur after deposition of the sediments but before their consolidation such as compaction or stirring by bioturbation contribute to the postdepositional remanent magnetization ( $\mathrm{pDRM}$ ). The ratio of DRM to $\mathrm{pDRM}$ depends on a number of factors such as grain size, rate of deposition, bioturbation and lock-in depths among others (Butler, 1992). Post-depositional remanence has a tendency to remove the inclination error. Chemical reactions may cause either alteration of pre-existing minerals to new kind of ferromagnetic minerals or precipitation of ferromagnetic minerals from solution. These minerals then acquire a magnetization (below their blocking temperature) in the magnetic field existing at the time of these changes termed as chemical remanent magnetization (CRM). One example of this would be production of a new hematite phase by dehydration of goethite, which in turn might be the product of an earlier alteration of $\mathrm{Fe}$ bearing silicates, to hematite and acquisition of CRM by the latter. The viscous remanent magnetization (VRM) is gradually acquired by the ferromagnetic grains because of their long-term exposure to weak magnetic field which commonly is the recent dipole field existing at the sampling site. From the magnetostratigraphic point of view, any magnetization other than DRM or pDRM can be regarded as noise. Proper magnetic cleaning techniques should be adapted to separate each magnetization type and isolate the DRM or pDRM for accurate polarity determination.

\section{Magnetization properties of Siwalik sediments in Nepal: a summary}

The data given here are derived from integrated laboratory study of pilot specimens of sandstone, siltstones and claystones collected from several sections. The experiments conducted are: NRM measurements with stepwise alternating field demagnetization (AFD: up to $150 \mathrm{mT}$ ) and thermal demagnetization (ThD: up to $700^{\circ} \mathrm{C}$ ), measurements of the initial magnetic susceptibility and its changes during stepwise heating, isothermal remanent magnetization (IRM) acquisition and demagnetization, and study of opaque minerals in polished thin sections (Appel et al. 1991, Gautam and Appel 1994, and Rösler et al., 1997).

Figure 5 shows the NRM data plotted against magnetic susceptibility for 3 sections. NRM intensity ranges between 0.1 to $100 \mathrm{mAm}^{-1}$ while bulk susceptibility lies between $10^{-5}$ and $10^{-2} \mathrm{SI}$ units. There is no visible correlation between these parameters in the range of intermediate and low values. Low susceptibility values are indicative of the significant contribution from paramagnetic particles. High values of susceptibility exceeding about 300 x $10^{-6}$ SI and very high NRMs are almost exclusively found in medium to coarse-grained 'pepper \& salt' sandstones. Relatively low coercivity spectra found during IRM acquisition 
(saturation gained below the applied field of c. 0.2 T; see Gautam and Appel, 1994) indicate that these sandstones contain maghemite (the ultimate low-temperature oxidation or weathering product of magnetite) or magnetite (Dunlop and Ozdemir, 1997; p. 445).

The NRM direction is a composite of: a) VRM residing on goethite (hard to AFD up to $150 \mathrm{mT}$, lack of complete saturation at $1.5 \mathrm{~T}$; and unblocking temperature of $100-120^{\circ} \mathrm{C}$ ) and also maghemite or magnetite (significant portion of intensity drop between $300-400^{\circ} \mathrm{C}$ or $400-600^{\circ} \mathrm{C}$ ). The VRM component is of normal polarity with a mean direction close to that expected from the present-day dipole field $\left(I=47^{\circ}\right)$ and is of secondary origin. b) Probably, a CRM or pDRM residing on pigmentary "soft" hematite (high coercivity but medium to high unblocking temperatures commonly around $600-620^{\circ} \mathrm{C}$ ). This component, of varying polarity, is not ubiquitous. It is not very well-defined and the mechanism of its acquisition is poorly understood, and c) DRM, occasionally with probable contribution from minor pDRM, as a characteristic primary remanence $(\mathrm{ChRM})$ residing in specular hematite (blocking temperatures reaching commonly to $640-700^{\circ} \mathrm{C}$, hard coercivities of $>150 \mathrm{mT}$ ). With welldefined normal (D/I: about $0^{\circ} / 20^{\circ}$ ) or reverse polarity (D/I: about $180^{\circ} /-20^{\circ}$ ) after bedding tilt-correction, it passes the reversal test and records inclination shallowing such that the ratio of the tangents of inclinations of the recorded ChRM and the expected field equals to about 0.45. Similar inclination errors are recorded by detrital remanence in sandstones sampled from the present-day riverbeds (Rösler et al., 1997).

The lower parts of the Siwalik sections with relatively high proportions of muddy and weathered varicolored lithologies contain abundant goethite that contributes up to $80 \%$ of initial NRM. Removal of the goethite-based VRM requires application of at least one heating step $\left(<150^{\circ} \mathrm{C}\right)$. A CRM based on hematite pigment requires demagnetization up to 600 $620^{\circ} \mathrm{C}$ not withstanding the fact that in some cases this process may lead to thermally induced chemical changes (e.g. alteration of clay minerals to magnetite or decomposition of goethite to hematite) and generation of spurious magnetizations between $400-600^{\circ} \mathrm{C}$ in the laboratory. On the other hand, sandy sections in the upper parts generally lacking in goethite or pigmentary hematite but containing magnetite/maghemite phases may be occasionally cleaned by AFD as well.

Results merely based on AFD are likely to contain predominantly spurious normal polarity intervals. The application of thorough stepwise $\mathrm{ThD}$ up to at least $600-620^{\circ} \mathrm{C}$ initially and then additional heating to complete demagnetization together with analysis of complete data set will be required to achieve a reliable polarity sequence. The extraction of weak ChRM through ThD requires the use of magnetometers with noise level better than $0.01 \mathrm{mAm}^{-1}$. Though the ChRM is contained in all lithologies (sandstones, siltstones and claystones), silty and sandy sediments (with preference to fine-grained if available) are more appropriate because of their availability throughout the Siwaliks, ease of sampling (in situ coring), possibility of heating without problems of sample break-down and measuring even with magnetometers requiring high-speed spinning (e.g. AGICO JR4 or JR5 spinner magnetometer)

\section{$\underline{\text { Rock magnetic parameters and their use for correlating sections }}$}

Rock magnetic parameters such as NRM and initial magnetic susceptibility magnitudes, temperature-dependent magnetization intensity ratios and IRM ratios, are found suitable for correlation. Their variations along continuous sections may permit detection of hiatus due to non-deposition or selective erosion, breaks in sections due to faulting or repetition by thrusting along a section and the direction of younging of rock sequence through mutual comparison of long sections. Intensity ratios $\Delta \mathrm{I}(\mathrm{T})=\left(\mathrm{I}_{\mathrm{NRM}^{-}} \mathrm{I}_{\mathrm{T}}\right) / \mathrm{I}_{\mathrm{T}}\left(\mathrm{T}=100^{\circ}\right.$ or 
$200^{\circ} \mathrm{C}, 400^{\circ} \mathrm{C}$ and $600^{\circ} \mathrm{C}$ ) indicate the relative contribution to the NRM by goethite, maghemite and magnetite/soft-coercivity hematite, respectively (Gautam and Appel, 1994). Similarly, the ratio $\mathrm{IRM}_{0.21 \mathrm{~T}} / \mathrm{IRM}_{1.5 \mathrm{~T}}$ is an inverse measure of magnetic hardness; the degree of its departure from unity towards lower values reflects the increase in the content of goethite and 'hard' hematite phases. The latter increases towards the younger parts of the sections implying proportional increase in the amount of soft magnetic minerals. Also, its cycles with wavelengths of about 100-200 m are recognizable. In the Surai Khola and Amiliya-Tui sections, its maxima always coincide with thick sandstone bodies. Integrated use of these parameters allows reasonable correlation of adjacent sections with an accuracy of few hundred meters (Rösler, 1998).

\title{
Magnetic Polarity Sequences and Depositional Chronology
}

Based on the published data, we consider the magnetic polarity sequences for various river and road sections by grouping them into three areas.

\section{The Surai Khola- Amiliya-Tui (SK-AT) area (Figs. 6 and 7)}

Data from the four sections belonging to this area are treated in detail in Appel et al. (1991), Rösler et al. (1997) and Rösler (1998). The sections are briefly described here.

\section{The Surai Khola (SK) section}

This section is exposed along the Mahendra Highway and the Surai Khola River (Fig. 6). Stratigraphic column is that shown in Fig. 2. This section lies within the southernmost imbricate slice bounded by the Main Frontal Thrust (MFT) in the south and the Rangsing Thrust in the north. This slice represents the southernmost of the 4 slices constituting about $25 \mathrm{~km}$ wide imbricate thrust package of the Siwalik rocks occurring south of the Main Boundary Thrust (MBT). Except for a $300 \mathrm{~m}$ stretch along the road near Dobata village, where the beds are sub-vertical showing overturning, the northerly dipping strata maintain north-side-up position throughout the section. In Fig. 7, the boundaries between the LowerMiddle Siwaliks (LS-MS) and the Middle-Upper Siwaliks (MS-US) are placed at $1330 \mathrm{~m}$ $3050 \mathrm{~m}$ from the base, respectively (SK, Fig. 7). Due to differences in calculation methods, the thickness for the Surai Khola section shown in Fig. 7 differs from that given in Fig. 2 by about $1.5 \%$ (i.e. $75 \mathrm{~m}$ ).

About $97 \%$ of the samples processed yield characteristic remanence (ChRM) and associated polarity. After removal of a secondary component below $150^{\circ} \mathrm{C}$, a stable direction persists up to $600^{\circ} \mathrm{C}$ in most samples so that the directions at about $400^{\circ} \mathrm{C}$ commonly represent stable endpoints. The Surai Khola section has an age span ranging from $13 \mathrm{Ma}$ to about <2 Ma. The boundaries LS to MS and MS to US fall at about 9.6 Ma and 5.2 Ma, respectively. Similarly, the most likely age intervals for the local formations/members are suggested as follows:

\author{
Bankas Formation: $\quad 13 \mathrm{Ma}-11.3 \mathrm{Ma}$ \\ Chor Khola Formation: 11.3 Ma - $8 \mathrm{Ma}$ \\ (Boundary of Jungli Khola and Shivgarhi members: at about 10.4 Ma) \\ Surai Khola Formation: $8 \mathrm{Ma}-4.9 \mathrm{Ma}$; \\ Dobata Formation: $4.9 \mathrm{Ma}-2.8$ ? Ma \\ Dhan Khola Formation: $<2.8 \mathrm{Ma}$
}

The Bhalubang (BB) section 
This is a road section along the Mahendra Highway to the east of Rapti River (Fig. 6). This section belongs to the second, seen from the south, imbricate slice bounded by Rangsing Khola Thrust and Siling Khola Back-Thrust (Dhital et al., 1995). Though ChRM directions are somewhat scattered in the multistoried MS part, polarity is well-defined.

\section{The Arjun Khola (AR) section}

This section has been sampled in two parts: southern part (ARs) - along the LamahiGhorahi dust road and Arjun Khola River, and northern part (ARn) - along the road between the Masot Khola bridge and a fault near the pass, which serves as the entrance to the Dang Dun. Both sub-sections occupy almost the same stratigraphic levels (LS and MS lithologies) and represent parts, separated by fault, of a large syncline (Metzler, 1993). Beds in the ARn section are overturned judging from fining upward sequences, mudcracks and cross-bedding features. About $20 \%$ of the samples showed generation of spurious remanence during $\mathrm{ThD}$ at or above $400^{\circ} \mathrm{C}$ in ARn. Here, poorly defined polarity for $1000-1300 \mathrm{~m}$ interval and the $1100-1227 \mathrm{~m}$ gap pose problems in matching the standard sequence. The polarity sequence in parts of the sections with long gaps in exposure is not defined.

\section{The Amiliya-Tui (AT) section}

This section is exposed along the motorable road between the Amiliya village situated east of Nepalganj at Mahendra Highway in Deokhuri valley and Tui Khola, south of Tulsipur in Dang valley. It comprises an overturned sequence of all LS, MS and US lithologies. The LS-MS and MS-US boundaries fall at $1360 \mathrm{~m}$ and $2510 \mathrm{~m}$ within the stratigraphic column (AT, Fig. 7). The strata are striking WNW-ESE and dipping due NNE with dip angles of about $60^{\circ}$. The section sampled consists of two overlapping parts along the road separated by big inner loop of the road at its central part where the rocks exhibit extreme weathering. Though rise of susceptibiity at or above $400^{\circ} \mathrm{C}$ in about $20 \%$ of samples and also occasional complex high-T remanence consisting of antipodal polarities were observed, the overall polarity resolution is good. IRM ratios are reproducible in two overlapping sections and allow their firm correlation. The rock magnetic parameters also confirm the overturning of the AT section inferred from sedimentary structures, and allow correlation of the SK and AT sections. According to such correlation, $0 \mathrm{~m}$ and $3000 \mathrm{~m}$ levels of the AT section correspond to $200 \mathrm{~m}$ and $2500 \mathrm{~m}$ levels of the SK section, respectively.

\section{The Arung Khola - Tinau Khola (AK-TK) area (Figs. 8 and 9)}

The lithostratigraphy in this area (Fig. 8) has been described by Tokuoka et al. (1986) (Fig. 2, middle column). The polarity patterns from eight sections, from east to west, have been taken from Tokuoka et al. (1986). The selection is based on better polarity resolution, denser sampling and lack of significant gaps - in the sections all in relative sense. The Arung Khola-Murali Khola (AM) section - the longest one and the Dang Khola section belong to the 'north belt', i.e. towards north of the Central Churia Thrust, whereas the other 6 sections belong to the 'south belt'. The polarity assignments are those made by Tokuoka et al. (1986) except for a few significant gaps, inferred from the published dataset, added newly by us . The data come from mudstone specimens treated by stepwise AFD up to $50 \mathrm{mT}$ during pilot phase and then subjected to blanket demagnetization at single peak field ranging between 15 $\mathrm{mT}$ and $40 \mathrm{mT}$. With the use of a Schonstedt spinner magnetometer SSM-1A (practical noise level of about $0.05 \mathrm{mAm}^{-1}$ ), eighty percent of samples are said to yield normal, intermediate or reverse polarities while a soft VRM of recent origin could be removed.

Data from the Tinau Khola section (TK, Figs. 8 and 9) are based on siltstone and sandstone samples treated with stepwise ThD (Gautam and Appel, 1994). A recent field 
overprint carried by goethite and maghemite was removed generally below $400-500^{\circ} \mathrm{C}$ revealing ChRM which allowed polarity resolution for $97 \%$ of the processed samples.

It is seen in Fig. 9 that the polarity pattern for the AM section contains relatively more details. Yet, there may be a bias to normal polarity towards the base where goethite present in variegated mudstone facies is expected to contribute to a secondary component which might have resisted AFD. Therefore, all the sections other than TK may be viewed as qualitative.

According to the new correlation, the age ranges covered by the AM and TK sections are 14-7 Ma and 11.4-6 Ma. The boundary between Arung Khola and Binai Khola Formations is at about 9.2 Ma. The boundaries Al-Am and Am-Au and Bl-Bm may be reasonably placed at $12.5 \mathrm{Ma}, 10.5 \mathrm{Ma}$ and $8.3 \mathrm{Ma}$, respectively. The horizon of Sivapithecus Punjabicus dated at c. 8.5 Ma in Gautam and Appel (1994) is now shifted to 9.31 Ma (near the base of chron 4Ar.1n; the change is caused by shifting of the base from $8.54 \mathrm{Ma}$ in GTS89 to 9.308 Ma in CK95). This new date now falls again within the 9.0-9.5 Ma range proposed by the authors who documented it (Munthe et al., 1983).

\section{The Rato Khola and Bakiya Khola areas}

The Rato Khola (RK) section

A $1630 \mathrm{~m}$ section (1151 m sampled for magnetostratigraphic study) is exposed along the Rato Khola River. It is accessible from the Mahendra Highway by a feather road to Sindhuli (Fig. 10). The section starts with Middle Siwalik rocks, gets stratigraphically older until a big bend of the river, continues up-section again and ends with cobble conglomerates of Upper Siwaliks several kms to the north. The strata are striking NNW-ESE with dips of about $30^{\circ}$ towards ENE. Owing to heat-induced chemical changes, recovery of ChRM by ThD above $400^{\circ} \mathrm{C}$ through well-defined stable points was possible in about $50 \%$ of samples. Interpretation of the part above $750 \mathrm{~m}$ is tentative because of rarer sampling dictated by abundance of very coarse lithologies. The tentative age assigned to this section is 5-2 Ma (Fig. 12).

\section{The Bakiya Khola (BK) section}

The magnetic polarity sequence from a $2600 \mathrm{~m}$ interval of the section exposed along the Bakiya Khola, accessible also from the Mahendra Highway, is based on ThD of siltstone and sandstone samples (Harrison et al., 1993). The strata generally have WNW-ESE strikes and $30-60^{\circ}$ dips due north. Lithologically, they were described as 'a part of the Lower Siwaliks (LS) or the lower part of the Middle Siwaliks (MS1)' by Harrison et al. (1993).

The lithostratigraphic divisions newly assigned by Ulak \& Nakayama (1998) and the location of the BK section are shown in Fig. 11. The lithostratigraphic nomenclature was given in Fig. 2 (right column). The lower 1000m of BK section corresponds to the Rapti Formation, and the top of the section extends to the middle part of the Upper Member of the Amlekhganj Formation. Correlation with CK95 suggests an age range of 11.1-5 Ma for the measured BK section. The boundary between the Rapti Formation and Amlekhganj Formation falls close to $8.5 \mathrm{Ma}$ (Fig. 12).

Summary of the magnetic polarity record from central Nepal Sub-Himalaya

Table 1 is a summary of paleomagnetic data for 12 sections. The mean paleomagnetic directions averaged for the age span given and grouped by polarity (normal or reverse) are presented along with other information which will be useful while assessing the data quality in future when more data will be available. Sections characterized by large $(>40-50 \mathrm{~m})$ 
effective sampling intervals and lacking in antipodality of normal and reverse components may not be used for quantitative estimates.

Depositional ages derived above suggest that caution should be exercised while attempting to correlate the individual lithostratigraphic units proposed by various authors. The first step towards broad chronostratigraphic correlations would be roughly equating the base of the Surai Khola Formation ( $8 \mathrm{Ma})$, the Bl-Bm boundary (8.3 Ma) and the base of the Amlekhganj Formation (8.5 Ma). However, interpretation of variations in rock chemistry, mineralogy, paleoclimate, or isotopic ratios with respect to time will be meaningful only if all the sampling sites are accurately attached to the measured sections which already have well-determined depositional chronology based on magnetostratigraphy. Differences may arise due to methods employed for estimating the thickness.

\section{Sediment accumulation rates}

Sediment accumulation rates (SARs) derived from 8 sections are shown in Fig. 13. As mentioned in the section 'Magnetic Polarity Stratigraphy', these CK95-based estimates have to be interpreted anew. Average SARs vary from 32 to $50 \mathrm{~cm} \mathrm{kyr}^{-1}$. Values of SAR for sections with short age range confined to the middle part of Siwaliks (e.g. ARn, ARs, BB) exceed $45 \mathrm{~cm} \mathrm{kyr}^{-1}$ whereas sections covering broad age and both LS, MS lithologies yield values commonly below $40 \mathrm{~cm} \mathrm{kyr}^{-1}$. Three broad time intervals (hatched in the diagram), probably significant to the uplift and erosion of the Himalayan source area, may be noted: i) 12-11 Ma (steady increase in sediment supply to the foredeep corresponding to first phase of gradual uplift of the source area); ii) 10.2-8.6 Ma (maximum sediment supply to the foredeep corresponding to maximum erosion of the source area); and, iii) 6.5-5.2 Ma (second phase of marked uplift of the source area). Somewhat variable SARs characterized the period between 8.5 and $7.5 \mathrm{Ma}$.

\section{Anisotropy of Magnetic Susceptibility and Fabric of Siwalik Sediments}

The low-field volumetric magnetic susceptibility $(\mathrm{k})$ is the ratio of the induced magnetization of a rock or mineral sample to a weak applied magnetic field. It is a fundamental rock magnetic property routinely measured during standard paleomagnetic measurements. The magnitude of $\mathrm{k}$ for a rock depends on the mineralogical composition, primarily on ferro/ferrimagnetic minerals (e.g., magnetite or maghemite: 2-3 SI, hematite: $\leq 6 \times 10^{-3} \mathrm{SI}$, goethite: about $3.5 \times 10^{-3} \mathrm{SI}$ ) but also on paramagnetic (mica and amphiboles: $10^{-4}$ SI, pyroxenes: $0.5-5 \times 10^{-3}$ SI, tourmaline: $1.69 \times 10^{-3}$ SI etc.) and diamagnetic minerals (e.g., quartz, calcite, feldspars: about $-14 \times 10^{-6} \mathrm{SI}$ ) (see Hrouda, 1982; Borradaile and Henry, 1997 and Rochette et al., 1992). It is sensitive to changes in mineral composition (e.g. production of new minerals during stepwise thermal demagnetization) especially of ferro-magnetic ones. In addition, the susceptibility in a natural rock may have anisotropy that can be determined at a level of the standard 1-inch diameter specimens used for routine paleomagnetic work. In the section below, general aspects related to anisotropy of susceptibility are given first, followed by the actual data derived from the Siwalik sections and their tentative interpretation.

\section{Anisotropy of Magnetic Susceptibility (AMS) as a fabric indicator}

The preferred orientation of grains and/or crystal lattice of minerals in a rock contribute to the anisotropy of magnetic susceptibility (AMS). The initial fabric in sediments like those of the Siwalik Group may result from alignment of oblate hematite grains having strong magnetocrystalline anisotropy parallel to the bedding or the shape alignment of 
elongated paramagnetic grains owing to various factors. Hydrodynamic forces, gravity and diagenetic compaction as well as the alignment of ferrimagnetic grains by the ambient geomagnetic field are important factors in undeformed sediments but even subtle internal deformations occurring later may modify the initial fabric.

The susceptibility $\mathrm{k}$ varies with the direction of measurement and it may be represented by a $3 \times 3$ symmetric second-rank tensor. This tensor is used to define a triaxial susceptibility ellipsoid, whose principal directions are $\mathrm{k}_{\max }$ (maximum susceptibility) $\geq \mathrm{k}_{\text {int }}$ (intermediate) $\geq \mathrm{k}_{\min }$ (minimum). On the scale of a site or section, clustered $\mathrm{k}_{\min }$ axes correspond to the pole of the 'magnetic foliation plane' whereas clustering of the $\mathrm{k}_{\max }$ axes defines the 'magnetic lineation'. In addition to the directions, the anisotropy may be almost completely characterized by the following three parameters (Jelinek, 1981):

i) The mean volume susceptibility $\left(k_{m}\right)$ as average of three eigenvalues representing the tensor:

$k_{m}=\frac{k_{\mathrm{max}}+k_{\mathrm{int}}+k_{\mathrm{min}}}{3}$

ii) The shape factor (T) defined as $T=\frac{\ln F-\ln L}{\ln F+\ln L}$; where, $L=\frac{k_{\max }}{k_{\text {int }}}$ and $F=\frac{k_{\text {int }}}{k_{\text {min }}}$ are the magnetic lineation and foliation, which are analogous to dimensional ratios, max/int and int/min, used to plot fabric strain data on a Flinn diagram. The value of $\mathrm{T}$ lies between -1 and +1 and it reflects the anisotropy quality. Its extreme values, i.e. -1 and +1 , point out to the prolate rotational (only the lineation is developed) and oblate rotational (only the foliation is developed) susceptibility ellipsoid, respectively. If the susceptibility ellipsoid is prolate, i.e. if the magnetic lineation is well-developed, then $-1<\mathrm{T}<0$. If the susceptibility ellipsoid is oblate, i.e. if the magnetic foliation is well-developed, then $0<\mathrm{T}<1$. If the susceptibility ellipsoid is neutral, i.e. if the magnetic lineation and foliation are developed to the same degree, then $\mathrm{T}$ is zero.

iii) Corrected degree of anisotropy $\left(\mathrm{P}^{\prime}\right)$ :

$$
P^{\prime}=\exp \sqrt{2\left[\left(\ln \frac{k_{\text {max }}}{k_{m}}\right)^{2}+\left(\ln \frac{k_{\text {int }}}{k_{m}}\right)^{2}+\left(\ln \frac{k_{\text {min }}}{k_{m}}\right)^{2}\right]}
$$

It defines the fabric intensity or anisotropy quantity by a measure of eccentricity of the magnitude ellipsoid. Between P', T and P (degree of anisotropy after Nagata, 1961), the following relationship exists:

$$
P^{\prime}=P^{\alpha} ; \text { Where } P=\frac{k_{\max }}{k_{\min }} \text {, and } \alpha=\sqrt{1+\frac{T^{2}}{3}}
$$

For a neutral anisotropy ellipsoid $(\mathrm{T}=0), \mathrm{P}^{\prime}=\mathrm{P}$ while for the limiting case of the rotational ellipsoid $(\mathrm{T}= \pm 1), \mathrm{P}^{\prime}=\mathrm{P}^{1.155}$ irrespective of the oblate or prolate shape.

\section{Development of fabric during deposition, diagenesis and mild tectonic deformation}

Gravitational and hydrodynamic forces largely determine the initial fabric in sediments. Hence, the size, shape and mass of the detrital grains and the velocity of the medium in which they are being transported control the overall fabric. According to laboratory studies on magnetic fabric of sedimentary rocks, either parallel or transverse fabric may be generated depending on hydrodynamic regime. Grain by grain (or from thin suspension) deposition from still or running water onto a flat or sloping bottom or by the 
deposition from highly concentrated grain dispersion onto a sloping bottom results in oblate susceptibility ellipsoid with the magnetic foliation dipping $<15^{\circ}$ (exceptionally $30^{\circ}$ ) from the bedding towards the origin of flow. The magnetic lineation in this case is subparallel to the flow direction with slight plunge towards the origin of flow. In contrast, deposition from medium-concentrated suspension generates very oblate (nearly rotational) susceptibility ellipsoids with magnetic foliation dipping $<15^{\circ}$ towards the origin of flow. In this case, the magnetic lineation tends to be perpendicular to the direction of flow (Hrouda and Potfaj, 1993; Rees, 1983).

Early post-depositional processes variously affect the initial fabric. Bioturbation tends to destroy depositional fabrics, thereby destroying depositional anisotropy. Early compaction may commonly lead to enhanced horizontal foliation because of the dominant role played by gravity. Late-diagenetic processes such as thickening of the overburden may further create a horizontal, oblate fabric or enhance any pre-existing fabric. With increasing compaction and cementation causing reduction in the pore space and permeability, rotation of grains will be more restricted. Authigenic magnetite grains or hematite flakes grown in association with the iron-bearing minerals such as clays, micas or even fossil tests along linear or planar structures marked by them are commonly found to enhance the pre-existing fabric. Permeability-controlled migration of gas and fluid even at greater depths may affect the fabric even after lithification. In some cases, the cement deposited along the fluid migration channels may mimic their shape and orientation. In short, the magnetic fabric recorded by a lithified sediment will depend on the multiplicity of factors that are responsible for change during the last stages of the diagenetic history of the sedimentary column (see Tarling and Hrouda, 1993 for details)

Tectonic deformation processes partially overprint the primary sedimentary fabric generating superposed fabric or completely modify it. Mathematical modelling of the initial phases of deformation shows that the magnetic lineation gets deflected away from the paleocurrent direction towards that of maximum elongation, i.e. perpendicular to the direction of rock shortening. This leads to the decrease of both $\mathrm{T}$ and $\mathrm{P}$ ' in the case of bedding parallel shortening. As the intensity of the strain increases, though it is still weak, the magnetic foliation tends to tilt away from the bedding plane, forming a girdle to planes parallel to the direction of shortening, i.e. perpendicular to maximum magnetic lineation.

\section{Contrasting AMS fabrics in compressive and extensional settings}

In compressive tectonic settings, magnetic lineations are detected to be approximately perpendicular to the local stress field (or subparallel to the local fold axes). Such fabric has been reported from apparently undeformed or weakly deformed Paleogene and Neogene sediments in orogenic belts in Northwest Greece, Taiwan, West Carpathians, western Taurus in Turkey and northern Apennines of Italy (Kissel et al., 1986; Lee et al., 1990; Hrouda and Potfaj, 1993; Aubourg et al., 1997; and Sagnotti et al., 1998). AMS may be used to define the 'true' shortening direction arising from the layer-parallel shortening resulting from pure shear that affects the whole sedimentary pile in external fold-thrust belts before folding, when the folds are oblique to the main tectonic transport direction (Aubourg et al., 1997). In extensional settings, however, the very first stages of deformation may produce well-defined magnetic lineation parallel to the maximum extensional direction in the bedding planes as recorded from the Plio-Pliestocene clayey units of the Tyrrhenian margin, central Italy (Sagnotti et al., 1994).

Anisotropy of magnetic susceptibility data for Siwalik sections 
AMS data based on low-field susceptibility measurements on standard specimens (1inch diameter cylindrical cores, 1 each from a particular stratigraphical height) are available for four sections. Measurements were made on a KLY-2 kappabridge using a 15-position rotatable pattern. Susceptibility magnitudes $\left(\mathrm{k}_{\mathrm{m}}\right.$ or bulk value at a single position) were shown earlier in relation to the NRM data for three sections (Fig. 5). The wide susceptibility range of $10^{-5}$ to $10^{-2} \mathrm{SI}$ results from contributions by a mixture of all dia-/para-/ferro-magnetic particles.

\section{Principal AMS directions}

Analysis of in situ principal susceptibility axes for the Tinau Khola section shows that $\mathrm{k}_{\min }$ or 'magnetic foliation pole' forms two (major and minor) clusters which coincide very well with similar clusters of poles to the bedding planes measured at the sampling sites. And, the axes $\mathrm{k}_{\max }$ and $\mathrm{k}_{\mathrm{int}}$ define girdle like distribution approximating planes (magnetic foliation planes) subparallel to the mean bedding planes (Gautam and Pant, 1996). This means that the measured fabric was basically formed before the tilting of the strata. Figure 14 shows $\mathrm{k}_{\max }$ and $k_{\min }$ axes for four (Amilia-Tui, Surai Khola, Tinau Khola and Rato Khola) sections. The pre-folding origin is evident from the well-defined sub-vertical cluster of $\mathrm{k}_{\min }$ axes as well as the sub-horizontal distribution of kmax axes.

Though sub-horizontal, the maximum axes $\left(\mathrm{k}_{\max }\right)$ trends exhibit some scattering. In the Amilia-Tui section, they are mainly confined in NW or SE quadrants whereas for the other three sections they lie mostly within $\pm 45^{\circ}$ from the east or the west. Analysis of the distributions of $\mathrm{k}_{\max }$ axes within several subsections constituting a given section reveals that the scattering is a common property of all subsections and systematic changes in trend are also absent. These findings suggest that the scattering of $\mathrm{k}_{\max }$ axes, within a particular section considered here, results from the statistical nature of the alignment process itself rather than from the differences in mineral composition, age or stratigraphic height. Assuming that these assumptions are valid, the mean values in each section will represent the best estimates of the aligning property (magnetic lineation). These values are estimated as the peak directions through density contouring and presented in Table 2. For the TK section, the better-defined normal polarity paleomagnetic direction (Table 1) has a declination of $341^{\circ}$ which deviates anticlockwise by at least $15^{\circ}$ from the declination expected during 11-6 Ma. A correction for this would bring the peak value for the TK section to $281^{\circ}$. Therefore, the peak magnetic lineation is about $280^{\circ}$ in the TK and RK sections. In the SK section, the peak lineation points to the west. For the AT section, it is NNW and differs by about $50-60^{\circ}$ from others.

\section{Anisotropy degree and shape characteristics}

Figure 15 shows the shape parameter plotted against the degree of anisotropy for four (Amilia-Tui, Surai Khola, Tinau Khola and Rato Khola) sections. The degree of anisotropy $\left(\mathrm{P}^{\prime}\right)$ is relatively low ( $<1.20$ excluding some extreme values correlated to specimens with extremely high mean susceptibility). According to shape parameter, most specimens plot into the oblate field $(\mathrm{T}>0)$. Depending on the section, the ellipsoids are prolate in $5-15 \%$ of the specimens. Values of $\mathrm{P}^{\prime}$ and $\mathrm{T}$ do not vary with stratigraphic level or age. However, the wide range of $\mathrm{P}^{\prime}$ found to be maximum for highly oblate specimens narrows down systematically with changes in shape towards prolate (through neutral) field. Though the mean $\mathrm{k}_{\max }$ direction is closely recorded by specimens with varying $\mathrm{P}^{\prime}$, the highest values $\left(\mathrm{P}^{\prime}>1.15\right)$ are confined to $\pm 30^{\circ}$ from the peak estimate. On the other hand, all specimens falling outside $\pm 60^{\circ}$ from the peak value have low values of $\mathrm{P}^{\prime}(<1.10)$. The uniformity in AMS magnitudes for sections distributed over a $400 \mathrm{~km}$ stretch is remarkable. 
Interpretation of Anisotropy of Magnetic Susceptibility Data

In order to interpret the observed AMS data discussed above, it will be worthwhile to summarize relevant data on paleocurent directions, bedding attitudes and tectonism.

\section{Paleocurrent data}

According to Tokuoka et al. (1986, 1990), the paleoflows in AK-TK area (Figs. 1 and 8) are generally southward. For the Arung Khola Formation (about 14-9.2 Ma), the paleoflows are towards SSE or SSW in the east but towards SW or W in the west. For the Binai Khola Formation $(<9.2 \mathrm{Ma})$, the inferred paleoflows are towards SSW in the eastern part but towards SW or W and towards SSE in the western part.

According to Burbank et al. (1996), paleocurrent directions for the Surai Khola section were towards SE during 13-11 Ma and 11-7Ma (Lower and Middle Siwalik times) but changed to S, E and W during the Pliocene (age of the analyzed Upper Siwalik sediments: $<4 \mathrm{Ma}$ ). These data are in line with their concept that the foreland depositional system results from contribution from axial (parallel to the orogenic axis) rivers during the early to middle Miocene times and transverse (perpendicular to the mountain front) rivers during the late middle Miocene times.

In contrast, Decelles et al. (1998) found average paleocurrent directions directed towards SSW (with an average of $208^{\circ}$ ) in the Surai Khola for both the Lower and Middle Siwaliks. In the Upper Siwaliks, the directions are more scattered but yield a fairly welldefined mean of about $200^{\circ}$. Hence, the rivers that deposited the Siwalik Group flowed consistently southward throughout the Siwalik deposition time.

From the data summarized above, paleocurrent data in the Nepalese Siwaliks may still be regarded as of local, fragmentary and controversial nature. In any case, either of the following two cases must be valid: i) the currents remained consistently southward; or, ii) they were directed to southeast during lower to middle Siwalik times but changed to roughly southward during the upper Siwalik time.

\section{Bedding and tectonic data}

Within a given section considered here, the strikes of the bedding planes have roughly similar trends. The major trends of strikes, excluding those for minor clusters found occasionally, are: ESE -WNW along the AT section, ENE-WSW along the SK section, E-W along the TK section and ESE-NNW along the RK section.

The Sub-Himalaya represents a foreland fold-thrust package sandwiched between the Main Boundary Thrust (MBT) in the north, a nearly flat-lying sole thrust at depth and the presently active Main Frontal Thrust (MFT) in the south. It exhibits traces of tectonic migration and convergence between the Indian plate and Eurasian Plate. The MBT is interpreted to have been active during early-middle and also probably the late Siwaliks times. The activity shifted to intra-Siwalik thrusts during late Siwalik time, and finally to the MFT sometimes during the Pleistocene time. Therefore, Siwalik sediments have been constantly affected by the north-south compression and related deformation together with the movements of strike-slip and rotation.

In the area of the AT section, south of the Dun valley of Dang, the intra-Siwalik thrusts are represented by distinct back-thrusts whose trends are about $315^{\circ}$ (Mugnier et al., 1995). The SK section is bounded by thrusts at both ends, namely the slightly imbricate Rangsing Thrust in the north and the almost bedding-parallel trace of the MFT in the south (Dhital et al., 1995). The fold-axes within the Sub-Himalayan thrust package around the SK area are always E-W oriented. The TK section lies south of the Central Churia Thrust or 
Dobhan Thrust (Yoshida and Arita, 1982) trending clearly W-E to WNW-ESE. The MFT to the south is discontinuous and poorly exposed. Accurate data on the fault trends in the vicinity of the RK section are not available.

\section{Interpretation of the AMS fabric}

To be brief, the AMS fabric in the Siwalik sediments considered is characterized by: i) predominantly oblate but also minor neutral and prolate ellipsoids; ii) weak in absolute terms (P'max =1.42) but variable degree of anisotropy P'; iii) grouping of the AMS directions after tilt-correction forming a cluster of magnetic foliation poles about the vertical indicative of a pre-folding origin of the foliation; iv) clustering of subhorizontal magnetic lineations almost symmetrically about peak orientation; and v) absence of significant variation in the directional pattern throughout a given section (Gautam and Pant, 1996).

Characteristics i) to iii) may favor a dominantly depositional sedimentary fabric (Tauxe et al., 1990; Gautam and Pant, 1996; and Rösler, 1998). But v) together with the lack of conformity of the estimated peak magnetic lineations to any of the two plausible paleocurrent directions, mentioned in 'paleocurrent data' above, suggest that the original fabric is no longer the dominant one. On the other hand, the peak magnetic lineation estimates are sub-parallel to the observed fold axes/strike of bedding planes/thrust fronts in the TK and SK sections and not so far for the AT sections (see the information presented above). These inferences indicate that probably tectonic deformation played an important role in forming the observed fabric. The pre-folding origin of the fabric and other characteristics observed here very much resemble those reported from the fine-grained sediments of the Messinian age deposited in foredeep basin at the front of the northern Apenninic mountain chain (Sagnotti et al., 1998). In analogy with their interpretation, the magnetic foliation is a relict of the initial fabric resulting from initial sedimentarycompaction process whereas the magnetic lineation was formed during the very first stages of deformation in a compressive setting. The prefolding origin of the observed fabric means that formation of such fabric was completed already before the folding started.

In light of the information presented above, the changes in the mean magnetic lineations in different sections may probably be attributed to the regional variations in the true shortening directions prevailing during the Siwalik deposition times in Nepal. The most probable direction of convergence for RK and TK sections would be about $\mathrm{N} 10^{\circ} \mathrm{E}$. For $\mathrm{SK}$ sections the convergence remained essentially towards north. The convergence direction for the area of AT section seems to have been around $\mathrm{N} 63^{\circ} \mathrm{E}$ being clearly different from the other areas. Differences between the peak lineations and the fold axes/bedding planes probably arise due to non-orthogonality between the latter and the direction of shortening or the tectonic transport direction owing to oblique thrusting.

Further accumulation of the AMS data and integrated analysis with structural observations in the Siwalik sediments will definitely contribute to our understanding and better interpretation of the magnetic fabric.

\section{Acknowledgements}

We are grateful to Erwin Appel for constant encouragement provided to us during the acquisition of substantial part of the material presented here. Constructive criticism by $\mathrm{K}$. Arita and detailed reviews P. Rochette, Robert F. Butler and an anonymous reviewer were of much help in improving the manuscript. P.G. gratefully acknowledges the advice and support extended by Y. Fujiwara during an Invited Fellowship granted by Japan Society for the Promotion of Science. 


\section{References}

Appel E., Rösler W. and Corvinus G. (1991) Magnetostratigraphy of the Miocene-Pleistocene Surai Khola Siwaliks in west Nepal. Geophys. J. Int. 105, 191-198.

Aubourg C., Frizon De Lamotte D., Poisson A. and Mercier E. (1997) Magnetic fabrics and oblique ramp-related folding: a case study from the western Taurus (Turkey). J. Struct. Geol. 19, 1111-1120.

Auden J.B. (1935) Traverse in the Himalaya. Rec. Geol. Surv. India 69(2), 123-167.

Barndt J., Johnson N.M., Johnson G.D., Opdyke N.D., Lindsay E.H., Pilbeam D. and Tahirkheli R.A.H. (1978) The magnetic polarity stratigraphy and age of the Siwalik Group near Dhok Pathan village, Potwar Plateau, Pakistan. Earth Planet Sci. Lett. 41, 355-364.

Barry J.C., Lindsay E.H. and Jacobs L.L. (1982) A biostratigraphic zonation of the Middle and Upper Siwalik of the Potwar Plateau of northern Pakistan. Palaeogeogr., Palaeoclimatol., Palaeoecol. 37, 95-130.

Berggren W.A., Kent D.V., Flynn J.J. and Van Couvering J.A. (1985) Cenozoic geochronology. Geol. Soc. Am. Bull. 96, 1407-1418.

Borraidale G.J. and Henry B. (1997) Tectonic applications of magnetic susceptibility and its anisotropy. Earth Science Reviews 42, 49-93.

Boving T. (1992) Lithostratigraphie und Geologie von mio-/ plio-/ pleistozänen Sedimenten der Surai Khola Siwaliks (West-Nepal) und Ratu Khola Siwaliks (Ost-Nepal). Diploma thesis, University of Tübingen.

Burbank D.W., Beck R.A. and Mulder T. (1996) The Himalayan foreland basin. In The Tectonic Evolution of Asia (Edited by Yin A. and Harrison M.), pp.149-188, Cambridge University Press.

Butler R.F. (1992) Paleomagnetism: Magnetic Domains to Geologic Terranes. Blackwell, Boston.

Cande S.C. and Kent D.V. (1992) A new geomagnetic polarity time scale for the last Cretaceous and Cenozoic. J. Geophys. Res. 97, 13,917-13,951.

Cande S.C. and Kent D.V. (1995) Revised calibration of the geomagnetic polarity timescale for the Late Cretaceous and Cenozoic. J. Geophys. Res. 100, 6093-6095.

Chaudhri R.S. (1982) Petrology of the Siwalik Group of Nepal Himalaya. Rec. Res. In Himalaya 8, 424-466.

Chaudhri R.S. and Gill G.T.S. (1981) Heavy mineral assemblage of the Siwalik Group of Nepal Himalaya. J. Geol. Soc. Of India 22, 220-226.

Corvinus G. (1993) The Siwalik Group of sediments at Surai Khola in Western Nepal and its paleontological record. Jour. Nepal Geol. Soc. 9, 21-35.

Corvinus G. and Nanda A.C. (1994) Stratigraphy and palaeontology of the Siwalik Group of the Surai Khola and Rato Khola in Nepal. N. J. Geol. Palaeont. Abh. 191, Stuttgart, Mainz, 25-68.

Cox A. (1973) Plate Tectonics and Geomagnetic Reversals. W. H. Freeman and Co., San Francisco.

Decelles P.G., Gehrels G.E., Quade J., Ojha T.P., Kapp P.A. and Upreti B.N. (1998) Neogene foreland basin deposits, erosional unroofing, and the kinematic history of the Himalayan fold-thrust belt, western Nepal. GSA Bulletin v. 110 (1), 2-21.

Dhital M.R., Gajurel A.P., Pathak D., Paudel L.P. and Kizaki K. (1995) Geology and structure of the Siwaliks and Lesser Himalaya in the Surai Khola-Bardanda area, mid Western Nepal. Bull. Dept. Geol., Tribhuvan Univ. 4, special issue,. 1-70. 
DMG (1987) Gological Map of Central Nepal (Scale 1:250,000). Published by the Director, Department of Mines and Geology, Kathmandu.

Flynn L.J., Pilbeam D., Jacobs L.L., Barry J.C., Behrensmeyer A.K. and Kappelman J.W. (1990) The Siwaliks of Pakistan: time and faunas in a Miocene terrestrial setting. $J$. Geology 98, 589-604.

Gansser A. (1964) Geology of the Himalayas. Wiley Interscience, London, 264pp.

Gautam P. and Appel E. (1994) Magnetic-polarity stratigraphy of Siwalik Group sediments of Tinau Khola section in west central Nepal, revisited. Geophys. J. Int. 117, 223-234.

Gautam P. and Pant S.R. (1996) Magnetic fabric of Siwalik Group sediments of Tinau Khola section, west central Nepal.Bull. Dept. Geol., Tribhuvan Univ. 5, 21-36.

Gill W.D (1951) The stratigraphy of the Siwalik series in the northern Potwar, Punjab, Pakistan. Quart. Jour. Geol. Soc. London 107(4), 375-394.

Greiner B. (1992) Geologische Untersuchungen im Amiliya-Tui Khola Gebiet (Siwaliks, West-Nepal). Diploma thesis, University of Tübingen.

Hagen T. (1969) Report on the Geological Survey of Nepal (preliminary reconnaissance). Denkschr. Schweiz. Naturf. Gessell. 86(1), 1-185.

Hailwood E.A. (1989) Magnetostratigraphy. Special Report No. 19, The Geological Society, Blackwell, Oxford.

Harland W. B., Cox A.V., Llewellyn C.A., Pickton G., Smith A.G. and R. Walters (1982) A geologic time scale. Cambridge Univ. Press, New York, 131 pp.

Harland W.B., Armstrong R.L., Cox A.V., Craig L.E., Smith A.G. and Smith D.G. (1990) The magnetostratigraphic time scale. In A geologic time scale 1989, Cambridge Univ. Press, Cambridge, 140-167.

Harrison T.M., Copeland P. Hall, S.A. Quade, J., Burner S., Ojha T.P. and Kidd W.S.F. (1993) Isotopic preservation of Himalayan/Tibetan uplift, denudation, and climatic histories in two molasse deposits. J. Geol. 101, 157-175.

Heirtzler J.R., Dickson G.O., Herron E.M., Pitman III W.C. and LePichon X. (1968) Marine magnetic anomalies, geomagnetic field reversals, and motions of the ocean floor and continents. J. Geophys. Res. 73, 2119-2136.

Herail G., Mascle G. and Delcaillau B. (1986) Les Siwaliks de l'Himalaya du Nepal: un exemple d'evolution geodynamique d'un prisme d'accretion intracontinental. In Evolution de domaines orogeniques d'Asie meridionale, livre jubilaire P. Bordet (Edited by Le Fort P., Colchen M. and Montenat C.) Sci. de la Terre, Nancy, mem. 47, pp.155-182.

Hilgen F.J. (1991a) Astronomical calibration of Gauss to Matuyama sapropels in the Mediterranean and implication for the geomagnetic polarity time scale. Earth Planet. Sci. Lett. 104, 226-244.

Hilgen F.J. (1991b) Extension of the astronomically calibrated (polarity) time scale to the Miocene/Pliocene boundary. Earth Planet Sci. Lett. 107, 349-368.

Hrouda F. (1982) Magnetic anisotropy of rocks and its application in Geology and Geophysics. Geophys. Surv. 5, 37-82.

Hrouda F. and Potfaj (1993) Deformation of sediments in the post-orogenic Intra-Carpathian Paleogene Basin as indicated by magnetic anisotropy. Tectonophysics 224, 425-434.

Itihara M., Shibasaki, T. and Miyamoto N. (1972) Photogeological survey of the Siwalik Ranges and the Terai Plain, southeastern Nepal. Jour. Geosci. Osaka City Univ. 15, 77-98. Jelinek V. (1981) Characterization of magnetic fabric of rocks. Tectonophysics 79, 563-567.

Johnson G.D., Zeitler P., Naeser C.W., Johnson N.M., Summers D.M., Frost C.D., Opdyke N.D. and Tahirkheli R.A.K. (1982) The occurrence and fission-track ages of Late Neogene 
and Quaternary volcanic sediments, Siwalik Group, northern Pakistan. Palaeogeogr. palaeoclimatol. palaeoecol. 37, 63-93.

Johnson G.D., Opdyke N.D., Tandon S.K. and Nanda A.C. (1983) The magnetic polarity stratigraphy of the Siwalik Group at Haritalyangar (India) and a new last appearance datum for Ramapithecus and Sivapithecus in Asia. Palaeogeogr. palaeoclimatol. palaeoecol. 44, 223-249.

Johnson N.M., Opdyke N.D., Johnson G.D., Lindsay E.H. and Tahirkheli R.A.K. (1982) Magnetic polarity stratigraphy and ages of Siwalik Group rocks of the Potwar Plateau, Pakistan. Paleogeogr. paleoclimatol. paleoecol. 37, 17-42.

Keller H.M., Tahirkheli R.A.K., Mirza M.A., Johnson G.D., Johnson N.M. and Opdyke N.D. (1977) Magnetic polarity stratigraphy of the Upper Siwalik deposits, Pabbi hills, Pakistan. Earth Planet Sci. Lett. 36, 187-201.

King R.F. (1955) Remanent magnetism of artificially deposited sediments. Mon. Notic. Roy. Astr. Soc., Geophysical Suppl. 7, 115-134.

Kissel C., Laj C. and Mazaud A. (1986) First paleomagnetic results from Neogene formations in Evia, Skyros and the Volos region and the deformation of central Aegea. Geophys. Res. Letters 13, 1446-9.

Le Fort P. (1989) The Himalayan orogenic segment. In Tectonic Evolution of the Tethyan Region (Edited by Sengor A.M. C.), Kluwer, pp.289-386.

Lee T. Q., Kissel C., Laj C., Horng C.S. and Lue Y.T. (1990) Magnetic fabric analysis of the Plio-Pleistocene sedimentary formations of the Coastal Range of Taiwan. Earth Planet Sci. Lett. 98, 23-32.

Lombard A. (1958) Un itinéraire géologique dans l'est du Népal (massif du Mont Everest). Mém. Soc. Helv. Sci. Nat. 82, 1-107.

Metzler W. (1993) Kartierung von jungtertiären Sedimenten des Arjun/Masot Khola Gebietes, Siwaliks, Südwestnepal. Diploma thesis, University of Tübingen.

Mugnier J.-L., Mascle G. and Faucher T. (1992) La structure des Siwaliks de l'ouest Nepal: un prisme d'accretion intracontinental. Bull. Soc. Geol. Fr. 163(5), 585-595.

Munthe J., Dongol B., Hutchison J.H., Kean W.F., Munthe K. and West R.M. (1983) New fossil discoveries from the Miocene of Nepal include a hominoid. Nature 303, 331-333.

Nagata T. (1961) Rock magnetism, Maruzen Co., Tokyo.

Opdyke N.D. (1990) Magnetic stratigraphy of Cenozoic terrestrial sediments and mammalian dispersal. J. Geology 98, 621-637.

Opdyke N.D., Lindsay E., Johnson G.D., Johnson N.M., Tahirkheli R.A.K. and Mirza M.A. (1979) Magnetic polarity stratigraphy and vertebrate paleontology of the Upper Siwalik subgroups of Northern Pakistan. Paleogeogr. paleoclimatol. paleoecol. 27, 1-34.

Pilgrim G.E. (1913) The correlation of the Siwaliks with mammal horizons of Europe. Rec. Geol. Surv. India 43(4), 264-326.

Rees A.I. (1983) Experiments on the production of transverse grain alignment in a sheared dispersion. Sedimentology 30, 437-448.

Renne P.R., Deino A.L., Walter R.C., Turrin B.D., Swisher III C.C., Becker T.A., Garniss H.C., Warren D.S. and Jaouni A.-R. (1994) Intercalibration of astronomical and radioisotopic time. Geology 22, 783-786.

Robin P.-Y.F. and Jowett. E. C. (1986) Computerized density contouring and statistical evaluation of orientation data using counting circles and continuous weighting functions. Tectonophysics 121, 207-223.

Rochette P., Jackson M. and Aubourg C. (1992) Rock magnetism and the interpretation of anisotropy of magnetic susceptibility. Reviews of Geophysics 30(3), 209-226. 
Rösler W. (1998) Magnetostratigraphy of Neogene fluvial sediments: results from a high resolution study and several new sections in the Nepalese Siwaliks. Tübinger Geowissenschaftliche Arbeiten, Reihe A, Band 38 (Ph. D. thesis, University of Tübingen, Germany), 81pp.

Rösler W., Metzler W. and Appel E. (1997) Neogene magnetic polarity stratigraphy of some fluviatile Siwalik sections, Nepal. Geophys. J. Int. 130, 89-111.

Sagnotti L., Faccenna, C., Funiciello R. and Massimo M. (1994) Magnetic fabric and structural setting of Plio-Pleistocene clayey units in an extensional regime: the Tyrrhenian margin of central Italy. J. Struct. Geol. 16(9), 1243-57.

Sagnotti L., Speranza F., Winkler A., Mattei M. and Funiciello R. (1998) Magnetic fabric of clay sediments from the external northern Apennines (Italy). Phys. Earth Planet. Int. 105, 73-93.

Sah R.B., Ulak P.D., Gajurel A.P. and Rimal L.N. (1994) Lithostratigraphy of Siwalik sediments of Amlekhganj-Hetauda area, Sub-Himalaya of Nepal. Him. Geol. 15, 37-48.

Tarling D.H. and Hrouda F. (1993) The Magnetic Anisotropy of Rocks. Chapman and Hall, London, 217pp.

Tauxe, L. and Kent D.V. (1984) Properties of a detrital remanence carried by haematite from study of modern river deposits and laboratory redeposition experiments. Geophys. J. R. Astron. Soc. 76, 543-561.

Tauxe L. and Opdyke N.D. (1982) A time framework based on magnetostratigraphy for the Siwalik sediments of the Khaur area, northern Pakistan. Palaeogeogr., Palaeoclimatol., Palaeoecol. 37, 43-61.

Tauxe L., Constable C., Stokking L. and Badgley C. (1990) Use of anisotropy to determine the origin of characteristic remanence in the Siwalik red beds of Northern Pakistan. $J$. Geophys. Res. 95, B4, 4391-4404.

Tokuoka T., Takayasu K., Hisatomi K., Yamasaki H., Tanaka S., Konomatsu M., Sah R. B. and Rai S.M. (1990) Stratigraphy and geologic structures of the Churia (Siwalik) Group in the Tinau Khola-Binai Khola area, West Central Nepal. Mem. Fac. Sci., Shimane Univ. 24, 71-88.

Tokuoka T., Takayasu K., Yoshida M. and Hisatomi K. (1986) The Churia (Siwalik) Group of the Arung Khola area, West Central Nepal. Mem. Fac. Sci., Shimane Univ. 20, 135-210.

Ulak P.D. and Nakayama K. (1998) Lithostratigraphy and evolution of fluvial style of the Siwalik Group in the Hetauda-Bakiya Khola area, Central Nepal. Bull. Dept. Geol., Tribhuvan Univ. 6 (in press).

Vine F.J. and Matthews D.H. (1963) Magnetic anomalies over ocean ridges. Nature 199, 947-949.

Yoshida M. and Arita K. (1982) On the Siwaliks observed along some routes in Central Nepal. J. Nepal Geol. Soc. 2, 59-66.

Wadia D.N. (1957) Geology of India. 3rd edition, Macmillan. 


\section{Tables and Figures}

Table 1. Summary of the mean paleomagnetic directions with associated statistical paramaters.

Table 1 Summary of the mean paleomagnetic directions with associated statistical paramaters

\begin{tabular}{|c|c|c|c|c|c|c|c|c|c|c|c|c|c|}
\hline \multirow[b]{2}{*}{$\begin{array}{l}\text { S. } \\
\text { No. }\end{array}$} & \multirow[b]{2}{*}{ Section } & \multirow[b]{2}{*}{$\begin{array}{l}\text { Age, Ma } \\
\text { (from-to) }\end{array}$} & \multirow[b]{2}{*}{$\mathrm{N}_{\mathrm{t}}$} & \multirow[b]{2}{*}{$\begin{array}{l}\text { Thickness } \\
\text { (m) }\end{array}$} & \multicolumn{6}{|c|}{ Mean Direction (bedding tilt-corrected) and statistics } & \multicolumn{3}{|c|}{ Additional sampling and laboratory details } \\
\hline & & & & & Polarity & $\mathrm{N}_{\mathrm{u}}$ & $\begin{array}{c}\text { Decli-natio } \\
\text { n } \\
\left({ }^{\circ}\right)\end{array}$ & $\begin{array}{l}\text { Incli-nati } \\
\text { on } \\
\left({ }^{\circ}\right)\end{array}$ & $\begin{array}{l}\alpha_{95} \\
\left({ }^{\circ}\right)\end{array}$ & $\mathrm{k}$ & $\begin{array}{c}\text { Lithology } \\
\text { used }\end{array}$ & $\begin{array}{l}\text { Spacing, } \\
\mathrm{m} \\
\mathrm{Se}(\mathrm{Sa})\end{array}$ & $\begin{array}{c}\text { Demag type, value(s) or } \\
\text { range } \\
\text { Peak/EP/PCA/GC }\end{array}$ \\
\hline 1 & $\begin{array}{l}\text { Amiliya } \\
\text {-Tui }\end{array}$ & $12.7-6.3$ & $\begin{array}{c}476 \\
+50^{*} \\
\end{array}$ & $\begin{array}{r}2967 \\
+320^{*} \\
\end{array}$ & $\begin{array}{l}\text { normal } \\
\text { reverse }\end{array}$ & $\begin{array}{l}207 \\
228\end{array}$ & $\begin{array}{c}0.4 \\
198.8 \\
\end{array}$ & $\begin{array}{c}18.9 \\
-17.2 \\
\end{array}$ & $\begin{array}{l}4.9 \\
4.3 \\
\end{array}$ & $\begin{array}{l}4.9 \\
4.3 \\
\end{array}$ & ss, sltst & $\begin{array}{c}6.8 \\
(6.2) \\
\end{array}$ & $\begin{array}{c}\text { Th to500 or } 700^{\circ} \mathrm{C} \\
\text { Peak/EP/PCA }\end{array}$ \\
\hline 2 & $\begin{array}{l}\text { Arjun } \\
\text { north }\end{array}$ & $11.8-8.3$ & $\begin{array}{c}126 \\
+14 * \\
\end{array}$ & 1667 & $\begin{array}{l}\text { normal } \\
\text { reverse }\end{array}$ & $\begin{array}{l}31 \\
77\end{array}$ & $\begin{array}{c}11.2 \\
176.5\end{array}$ & $\begin{array}{c}21.8 \\
-18.9\end{array}$ & $\begin{array}{c}13.6 \\
9.9\end{array}$ & $\begin{array}{l}4.6 \\
3.7 \\
\end{array}$ & ss, sltst & $\begin{array}{c}15.4 \\
(13.2)\end{array}$ & $\begin{array}{c}\text { Th to500 or } 700^{\circ} \mathrm{C} \\
\text { Peak/EP/PCA }\end{array}$ \\
\hline 3 & $\begin{array}{l}\text { Arjun } \\
\text { south }\end{array}$ & $11.5-7$ & $\begin{array}{c}115 \\
+12 * \\
\end{array}$ & 2232 & $\begin{array}{l}\text { normal } \\
\text { reverse }\end{array}$ & $\begin{array}{l}31 \\
42 \\
\end{array}$ & $\begin{array}{c}1.9 \\
179.0\end{array}$ & $\begin{array}{c}31.1 \\
-20.0 \\
\end{array}$ & $\begin{array}{l}9.3 \\
4.9 \\
\end{array}$ & $\begin{array}{c}8.7 \\
11.2 \\
\end{array}$ & ss, sltst & $\begin{array}{c}30.6 \\
(19.4) \\
\end{array}$ & $\begin{array}{c}\text { Th to500 or } 700^{\circ} \mathrm{C} \\
\text { Peak/EP/PCA }\end{array}$ \\
\hline 4 & $\begin{array}{l}\text { Bhalu- } \\
\text { bang }\end{array}$ & $11.5-7.6$ & 123 & 1890 & $\begin{array}{l}\text { normal } \\
\text { reverse }\end{array}$ & $\begin{array}{l}32 \\
44 \\
\end{array}$ & $\begin{array}{c}9.5 \\
182.9 \\
\end{array}$ & $\begin{array}{r}29.7 \\
-21.1 \\
\end{array}$ & $\begin{array}{l}12.4 \\
11.1 \\
\end{array}$ & $\begin{array}{l}5.1 \\
4.8 \\
\end{array}$ & ss, sltst & $\begin{array}{c}24.9 \\
(15.4) \\
\end{array}$ & $\begin{array}{c}\text { Th to500 or } 700^{\circ} \mathrm{C} \\
\text { Peak/EP/PCA }\end{array}$ \\
\hline 5 & $\begin{array}{l}\text { Surai } \\
\text { Khola }\end{array}$ & $13-<2$ & 596 & 5049 & $\begin{array}{l}\text { normal } \\
\text { reverse }\end{array}$ & $\begin{array}{l}295 \\
265\end{array}$ & $\begin{array}{l}359.5 \\
179.2 \\
\end{array}$ & $\begin{array}{c}12.1 \\
-23.2 \\
\end{array}$ & $\begin{array}{l}3.8 \\
4.3 \\
\end{array}$ & $\begin{array}{l}5.7 \\
5.0\end{array}$ & ss, sltst & $\begin{array}{c}9.0 \\
(8.5)\end{array}$ & $\begin{array}{c}\text { Th to500 or } 700^{\circ} \mathrm{C} \\
\text { Peak/EP/PCA }\end{array}$ \\
\hline 6 & $\begin{array}{l}\text { Tinau } \\
\text { Khola }\end{array}$ & $11.4-6$ & $\begin{array}{c}128 \\
+18^{*} \\
\end{array}$ & $\begin{aligned} & 1710 \\
&+ 120^{*} \\
&\end{aligned}$ & $\begin{array}{l}\text { normal } \\
\text { reverse }\end{array}$ & $\begin{array}{l}63 \\
61 \\
\end{array}$ & $\begin{array}{l}341.1 \\
172.6 \\
\end{array}$ & $\begin{array}{r}22.7 \\
-20.1 \\
\end{array}$ & $\begin{array}{l}8.9 \\
7.9 \\
\end{array}$ & $\begin{array}{l}5.9 \\
6.4 \\
\end{array}$ & ss, sltst & $\begin{array}{c}13.8 \\
(13.3) \\
\end{array}$ & $\begin{array}{l}\text { Th to500 or } 675^{\circ} \mathrm{C} \\
\text { Peak/EP/PCA/GC }\end{array}$ \\
\hline 7 & $\begin{array}{l}\text { Satbudn } \\
\text { Nala }\end{array}$ & $11-8 ?$ & 20 & 1500 & $\begin{array}{l}\text { normal } \\
\text { reverse }\end{array}$ & $\begin{array}{c}16 \\
1\end{array}$ & 8.2 & 22.6 & 16.5 & 6.0 & mdst & $\begin{array}{l}88.2 \\
(75)\end{array}$ & $\begin{array}{c}\mathrm{AF} \quad 30 \mathrm{mT} \\
\text { Peak/EP }\end{array}$ \\
\hline 8 & $\begin{array}{l}\text { Madari } \\
\text { Khola } \\
\end{array}$ & $8.5 ?-6 ?$ & 13 & 1400 & $\begin{array}{l}\text { normal } \\
\text { reverse }\end{array}$ & $\begin{array}{l}7 \\
6 \\
\end{array}$ & $\begin{array}{l}338.6 \\
122.6 \\
\end{array}$ & $\begin{array}{c}26.0 \\
-38.6 \\
\end{array}$ & $\begin{array}{l}28.6 \\
27.7 \\
\end{array}$ & $\begin{array}{l}5.4 \\
6.8 \\
\end{array}$ & mdst & $\begin{array}{c}107.7 \\
(107.7) \\
\end{array}$ & $\begin{array}{c}\text { AF } 30 \mathrm{mT} \\
\text { Peak/EP }\end{array}$ \\
\hline 9 & $\begin{array}{l}\text { Arung K. - } \\
\text { Murali K. }\end{array}$ & $14-7 ?$ & 90 & 3435 & $\begin{array}{l}\text { normal } \\
\text { reverse }\end{array}$ & $\begin{array}{l}36 \\
33\end{array}$ & $\begin{array}{l}355.3 \\
159.3 \\
\end{array}$ & $\begin{array}{r}19.9 \\
-23.8 \\
\end{array}$ & $\begin{array}{l}10.9 \\
10.2\end{array}$ & $\begin{array}{l}5.6 \\
7.0\end{array}$ & mdst & $\begin{array}{c}49.8 \\
(38.2)\end{array}$ & $\begin{array}{c}\text { AF }<50 \mathrm{mT} \\
\text { Peak/EP }\end{array}$ \\
\hline 10 & $\begin{array}{l}\text { Dang } \\
\text { Khola }\end{array}$ & $10-7$ & 40 & 1750 & $\begin{array}{l}\text { normal } \\
\text { reverse }\end{array}$ & $\begin{array}{l}11 \\
18\end{array}$ & $\begin{array}{l}345.7 \\
162.5\end{array}$ & $\begin{array}{c}5.3 \\
-20.5 \\
\end{array}$ & $\begin{array}{l}17.9 \\
16.1\end{array}$ & $\begin{array}{c}7.4 \\
15.6\end{array}$ & mdst & $\begin{array}{c}60.3 \\
(43.5)\end{array}$ & $\begin{array}{c}\mathrm{AF} 30 \mathrm{mT} \\
\text { Peak /EP }\end{array}$ \\
\hline 11 & $\begin{array}{l}\text { Bakiya } \\
\text { Khola }\end{array}$ & $11.1-5$ & 101 & 2600 & $\begin{array}{l}\text { normal } \\
\text { reverse }\end{array}$ & $\begin{array}{l}41 \\
33 \\
\end{array}$ & $\begin{array}{c}\cong 0 \\
\cong 180\end{array}$ & & & & ss, sltst & $\begin{array}{c}35.1 \\
(25.8)\end{array}$ & $\begin{array}{l}\text { Th to500 } \\
\text { Peak/PCA } \\
\text { Pea }\end{array}$ \\
\hline 12 & $\begin{array}{l}\text { Rato } \\
\text { Khola }\end{array}$ & $5-2 ?$ & 77 & 1151 & $\begin{array}{l}\text { normal } \\
\text { reverse }\end{array}$ & $\begin{array}{l}40 \\
28\end{array}$ & $\begin{array}{c}6.9 \\
170.2\end{array}$ & $\begin{array}{c}32.2 \\
-41.0\end{array}$ & $\begin{array}{l}10.4 \\
17.4\end{array}$ & $\begin{array}{l}5.7 \\
3.4\end{array}$ & ss, sltst & $\begin{array}{c}16.9 \\
(14.9)\end{array}$ & $\begin{array}{c}\text { Th to500 or } 700^{\circ} \mathrm{C} \\
\text { Peak/EP/PCA }\end{array}$ \\
\hline
\end{tabular}

Note: Age based on correlations with GPTS CK95. $\mathrm{N}_{\mathrm{t}}$ : total no. of samples processed (* denotes processed but not used for various reasons (e.g. repeated part of the section). Nu: no. of usable samples/specimens/levels. D and I denote the declination $\left(0\right.$ to $\left.360^{\circ}\right)$ and inclination $\left(-90\right.$ to $+90^{\circ}$ : upwards negative and downwards positive) of the mean paleomagnetic vector calculated using Fisherian statistics ( $\alpha_{95}$ : radius of confidence circle at $95 \%$ level and k: precision parameter). ss, sltst and mdst refer to sandstone (fine-to medium grained), compact siltstone and mudstone. Se(Su): average effective and actual sampling interval in $\mathrm{m}$. Demag: demagnetization type, alternating field (AF) or thermal (Th) with applied ranges of fields (mT: millitesla) or temperatures. Peak/EP/PCA/GC denote type of analysis such as blanket, stable end-point, principal component analysis or great circle options. Compiled using published original data after Rösler et al. , 1997 (sections 1-5 and 12); Gautam and Appel, 1994 (section 6); Tokuoka et al. , 1986 (sections 7-10); and Harrison et al. , 1993 (section 11).

Table 2. Statistical parameters for AMS maximum directions (magnetic lineations).

Table 2 Statistical parameters for AMS maximum directions

\begin{tabular}{|l|c|cc|c|c|c|c|c|}
\hline \multirow{1}{*}{ Section } & \multirow{2}{*}{$\begin{array}{c}\text { Age (Ma) } \\
\text { (from-to) }\end{array}$} & \multicolumn{2}{|c|}{ Peak direction } & \multicolumn{5}{c|}{ Statistical parameters } \\
\cline { 3 - 9 } & & $\begin{array}{c}\text { Trend } \\
\left(^{\circ}\right)\end{array}$ & $\begin{array}{c}\text { Plunge } \\
\left(^{\circ}\right)\end{array}$ & $\mathrm{N}$ & $\mathrm{k}$ & $\mathrm{E}$ & $\mathrm{s}$ & $\mathrm{V}$ \\
Amilia -Tui & $12.7-6.3$ & 333.4 & 7.6 & 420 & 47.67 & 4.41 & 1.47 & 4.41 \\
Surai Khola & $13-<2$ & 272.5 & 4.6 & 255 & 58.67 & 4.35 & 26.38 & 26.38 \\
Tinau Khola & $11.4-6$ & 266.0 & 4.7 & 112 & 26.89 & 4.17 & 1.39 & 30.4 \\
Rato Khola & $5-2 ?$ & 280.8 & 11.9 & 49 & 6.44 & 3.80 & 12.39 & 12.39 \\
\hline
\end{tabular}

Note: Parameters based on density contouring using the Gaussian smoothing $(\mathrm{E}=3$ sigma) option (Robin \& Jowett, 1986). $\mathrm{N}$ is no. of specimens/sampling levels; $\mathrm{k}$ is counting function calculated as $2(1+\mathrm{N} / 9)$; $\mathrm{E}$ is expected value; $\mathrm{s}$ is dispersion; and $\mathrm{V}$ (value) is calculated as (peak-E)/s. 


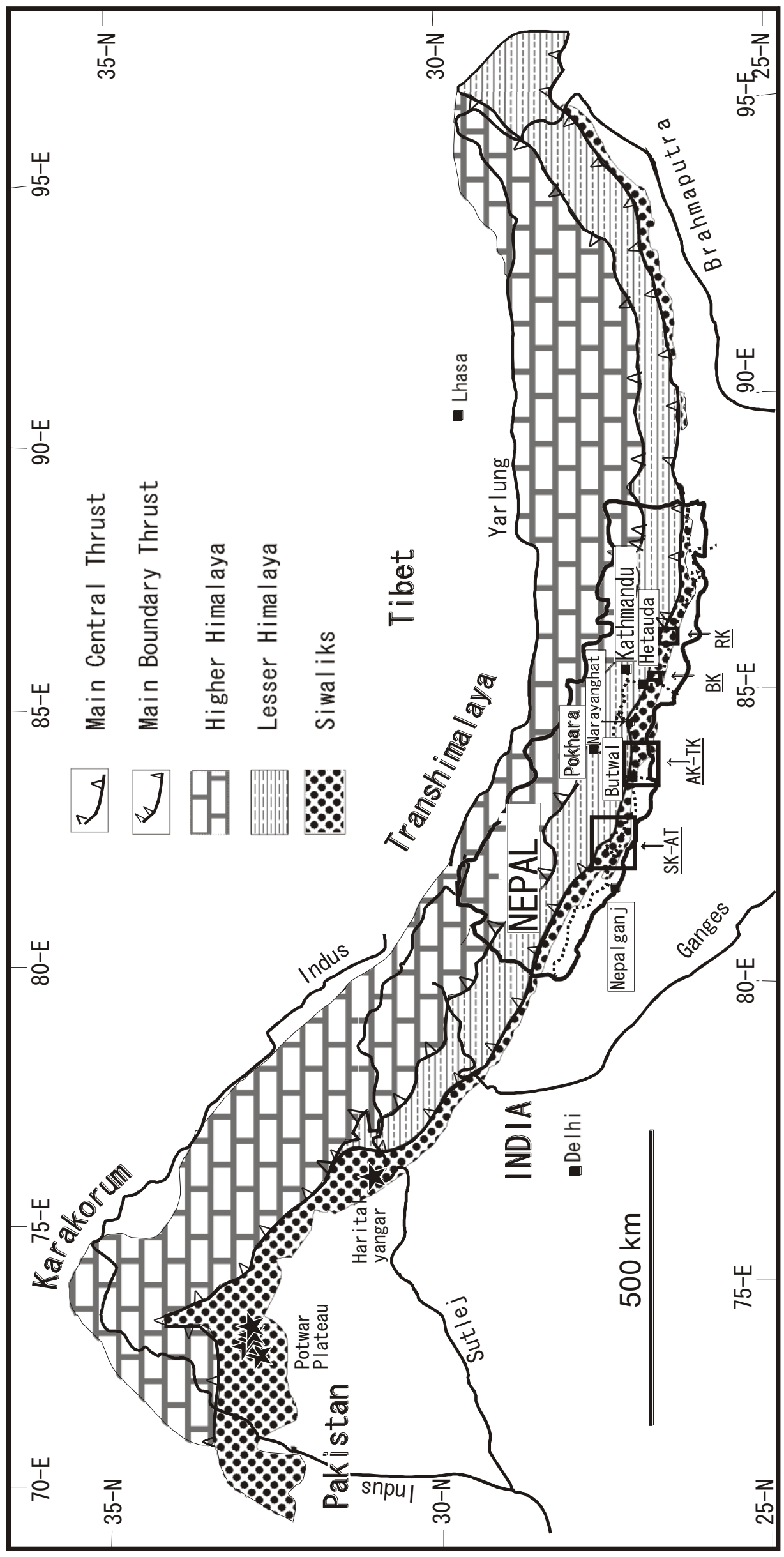

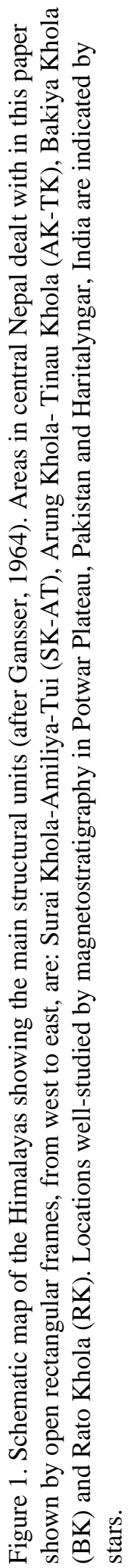


(m)

6000

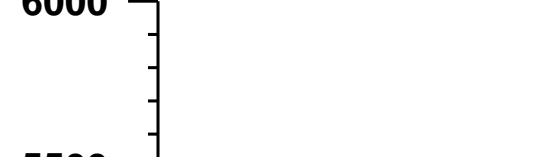

Surai Khola area

Road Section

(Dhital et al., 1995)

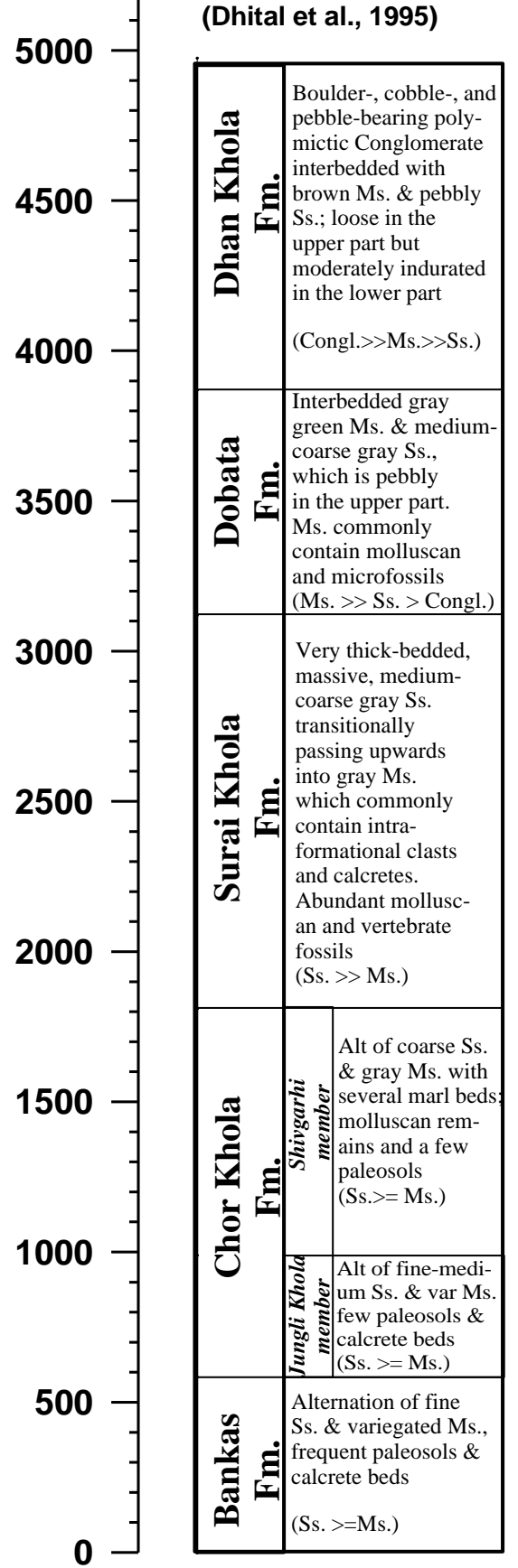

Arung Khola-Binai

Khola area

(Tokuoka et al., 1986)

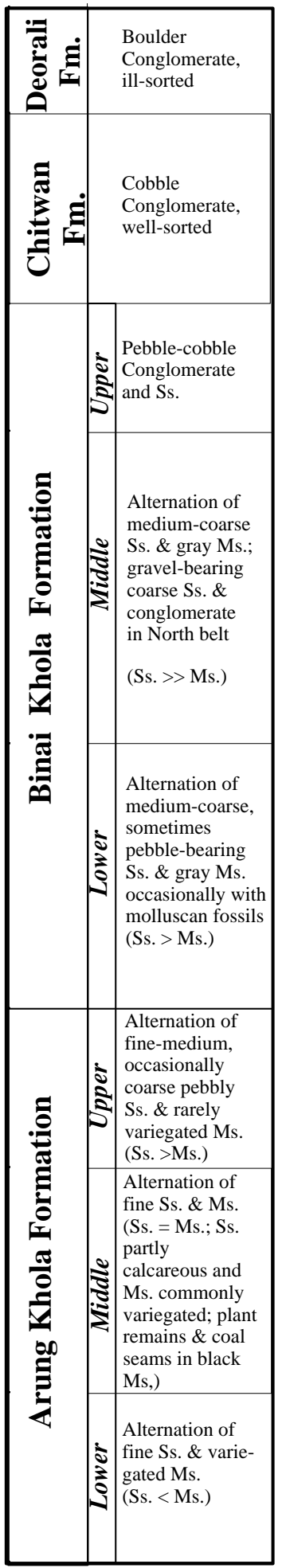

Hetauda-Bakiya

Khola area

(Ulak \& Nakayama, 1998)

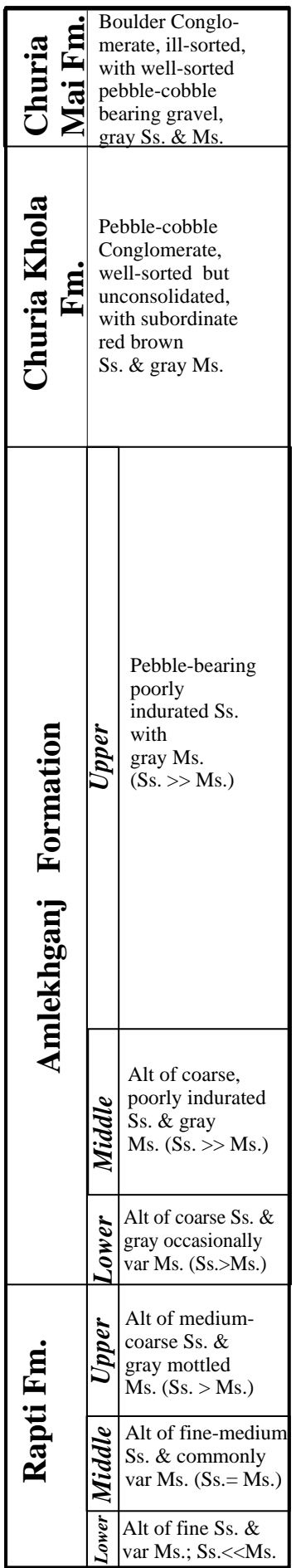

Figure 2. Comparison of three local lithostratigraphic schemes with formation nomenclatures used currently in the Siwaliks of Central Nepal. For the Surai Khola section, the thickness observed comes from a single traverse. For the other two sections, the thickness of each formation corresponds to the maximum reported from observations in the north and south belts (separated by Central Churia Thrust). No direct correlation is shown due to diverse lithological criteria adapted. Depositional ages derived from magnetic polarity for measured sections are discussed in the text and shown in subsequent figures. 


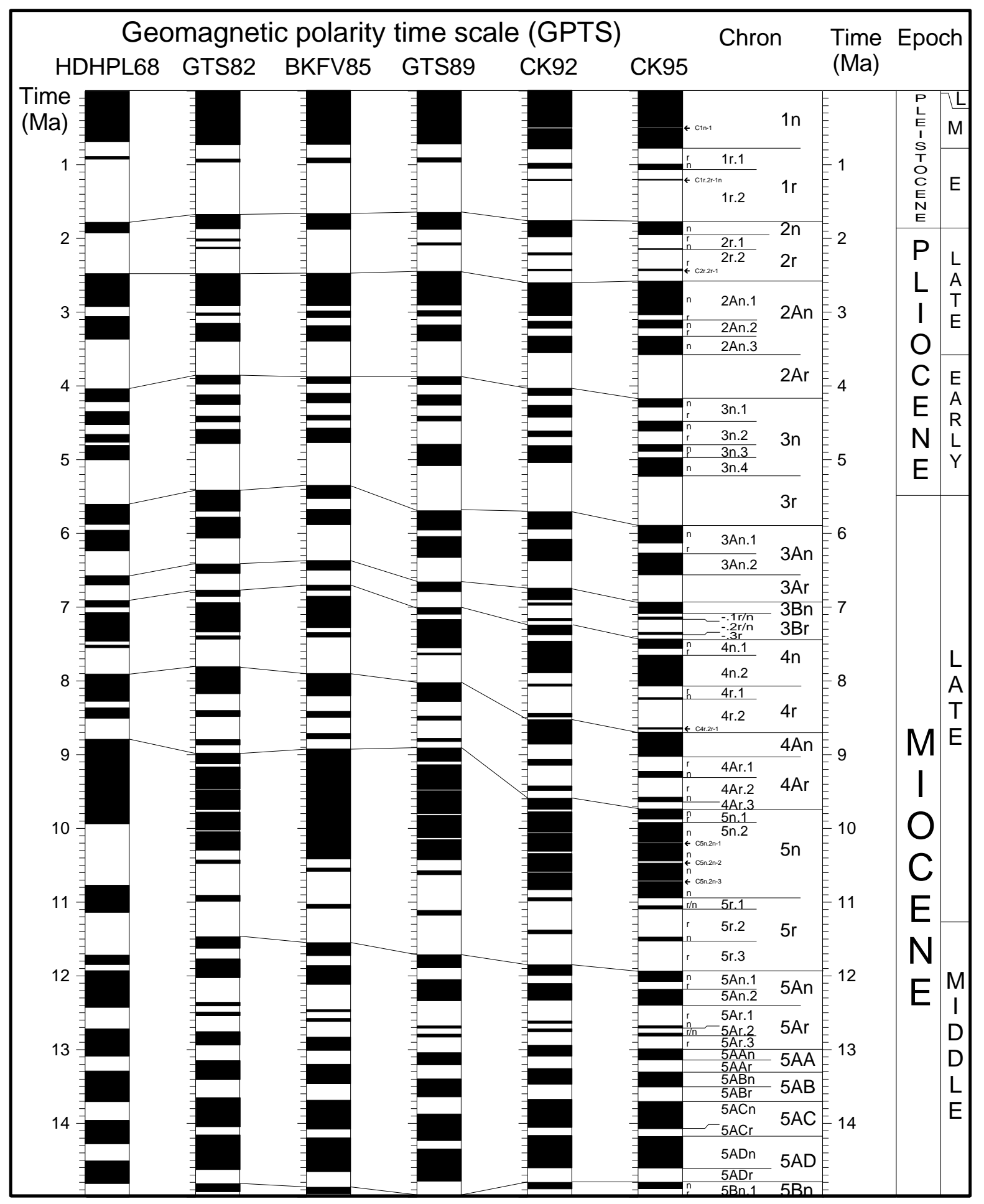

Figure 3. Development of the pattern and the chronometrical calibration of the Geomagnetic Polarity Time Scale (GPTS) for the last 15 Ma. HDHPL68: Heirtzler et al. (1968); GTS82; GTS89: Harland et al. (1982; 1990); BKFV85: Berggren et al. (1985); CK92; CK95: Cande and Kent (1992; 1995). The polarity sequences established by various workers in central Nepal are newly correlated to CK95. 


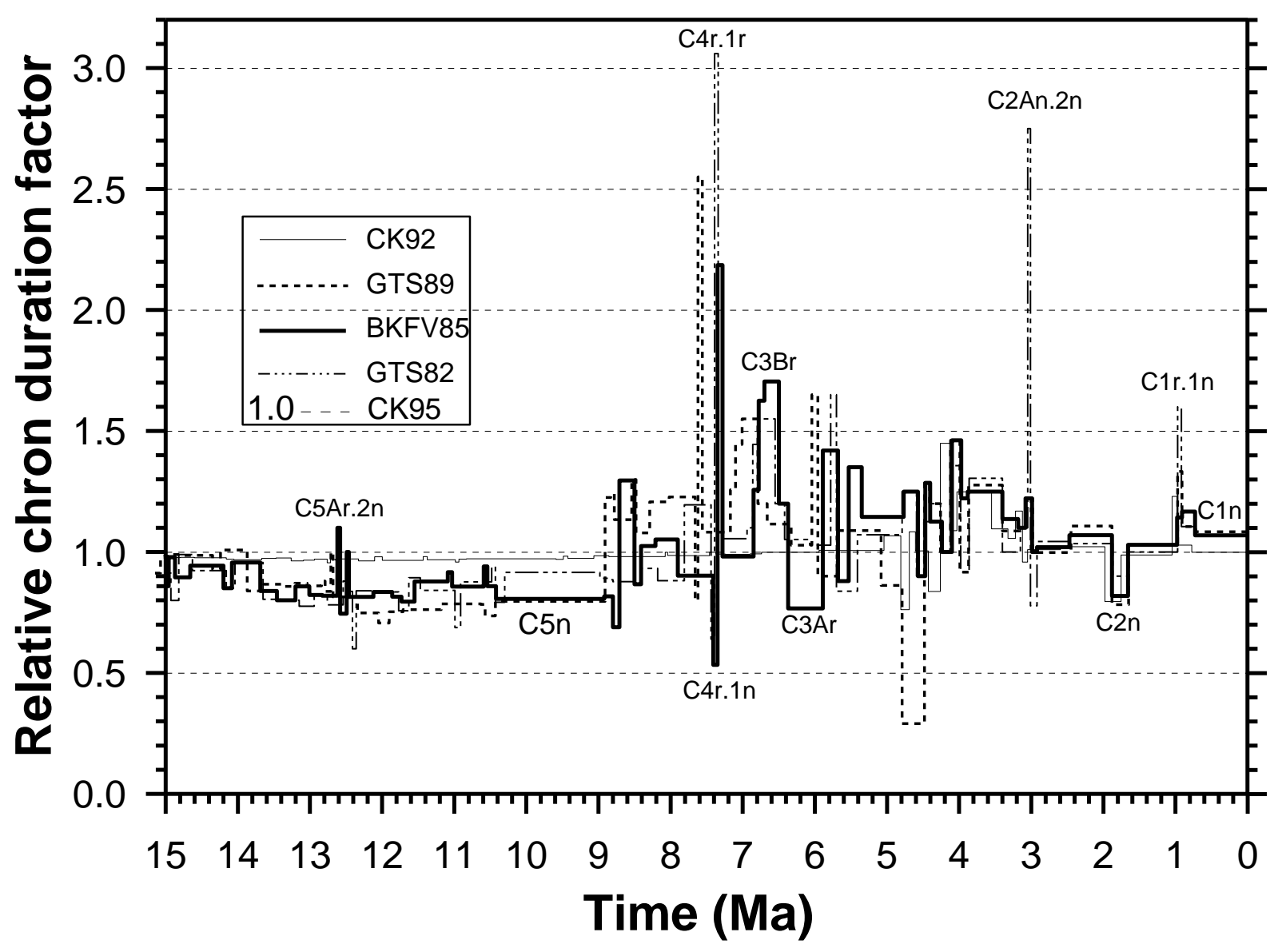

Figure 4. Relative chron duration factor versus time curve. The former is calculated as the ratio of $\Delta t$ CK95 (duration of a particular magnetic polarity interval of $\mathrm{CK}_{95}$ ) to $\Delta \mathrm{t}$ Ts (duration of correlated polarity interval in other global polarity time scale in question, i.e. one of the scales from GTS82, GTS89, BKFV85 and CK92). The factor has a magnitude equal to the height of horizontal bar shown against the time span equal to the length of the bar. Note that only the polarity intervals which are easily identified in all these time scales are considered. Selected chron names are shown for orientation. If CK95 is taken as the most correct time scale, the height of each bar is a scaling factor by which the previously determined time-spans or sediment accumulation rates based on an older version of time scale must be corrected. Distortions greater than a factor of two are limited to very short intervals. The relative shift of a boundary, resulting in a relative increase and decrease in the adjacent intervals, is seen as a pair of adjacent opposite values. 
Figure 5. Relationship between the initial magnetic susceptibility and the natural remanent magnetization (bilogarithmic plot) in three sections. $\mathrm{N}$ indicates the number of core specimens/sampling levels measured. Specimens are identified by different symbols to differentiate their belonging either to LS, MS, US (traditional Lower, Middle, Upper Siwaliks nomenclature) or $\mathrm{AK}, \mathrm{Bl}$ and $\mathrm{Bm}$ (Arung Khola, Binai Khola (lower and middle) Formations). Points extending middle to upper right side (i.e. with proportional relationship) indicate relatively high magnetite and/or maghemite concentrations. Susceptibility values lower than $3 \times 10$ 4 SI result from mainly paramagnetic contribution.
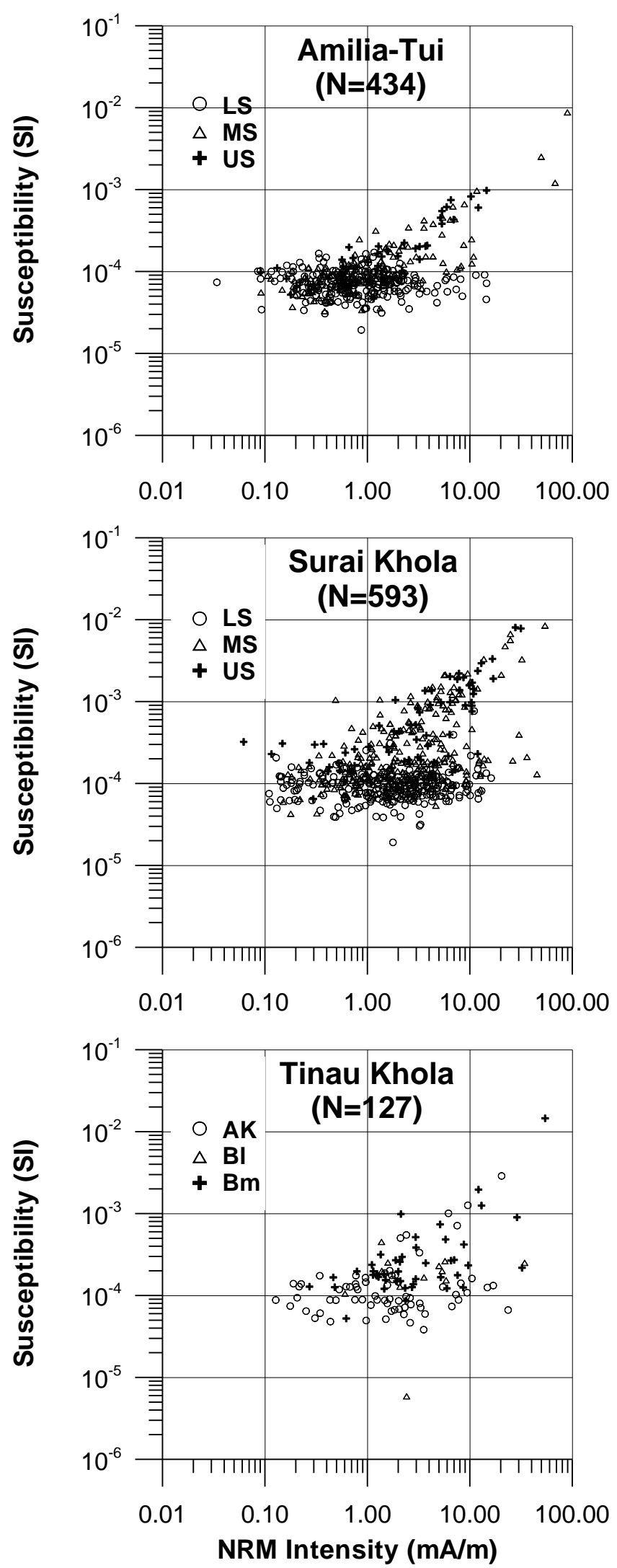


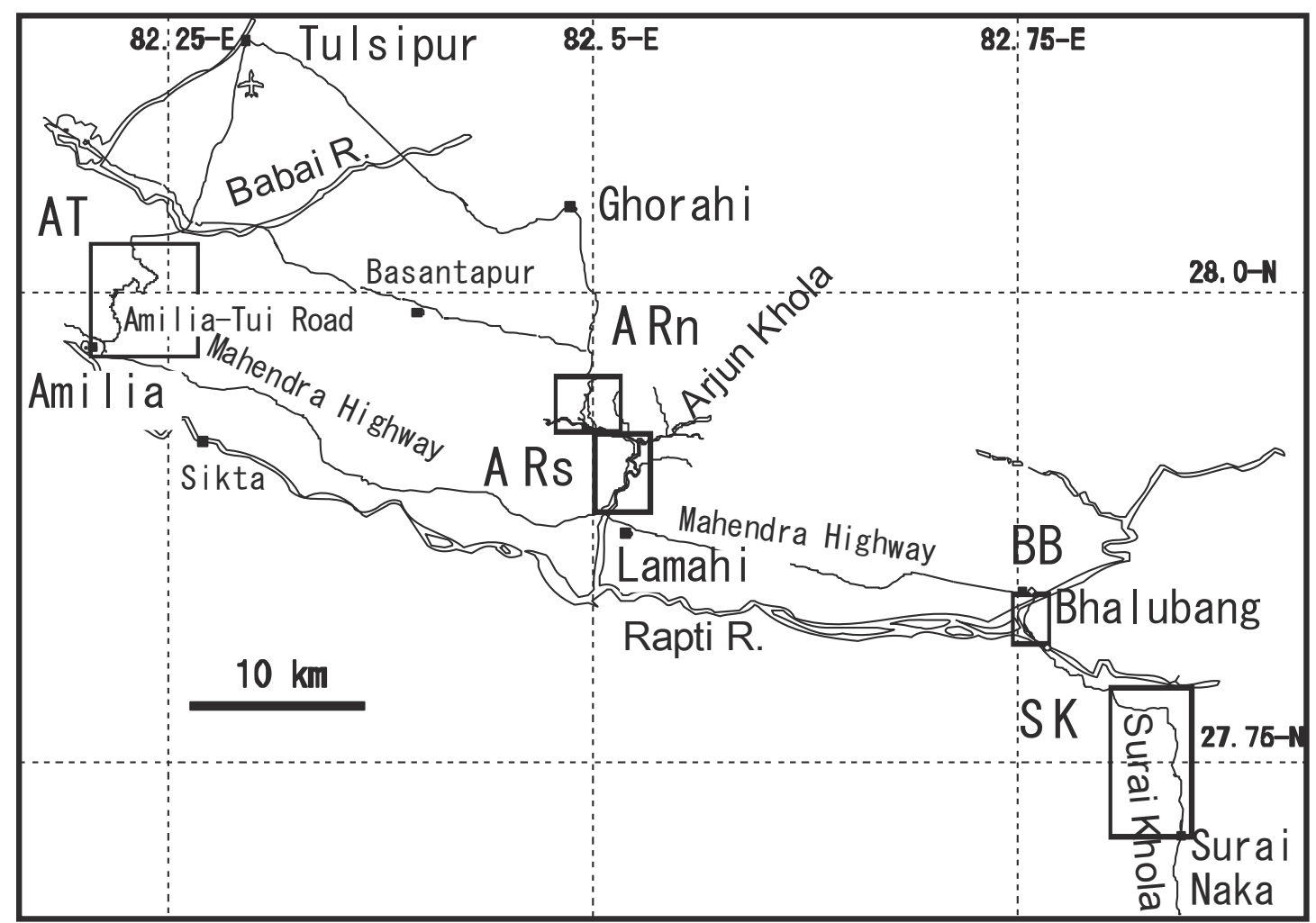

Figure 6. Sketch map of Surai Khola - Amiliya-Tui (SK-AT) area with locations of the studied sections whose polarity sequences are shown in Fig. 7 (modified after Rösler et al., 1997). 


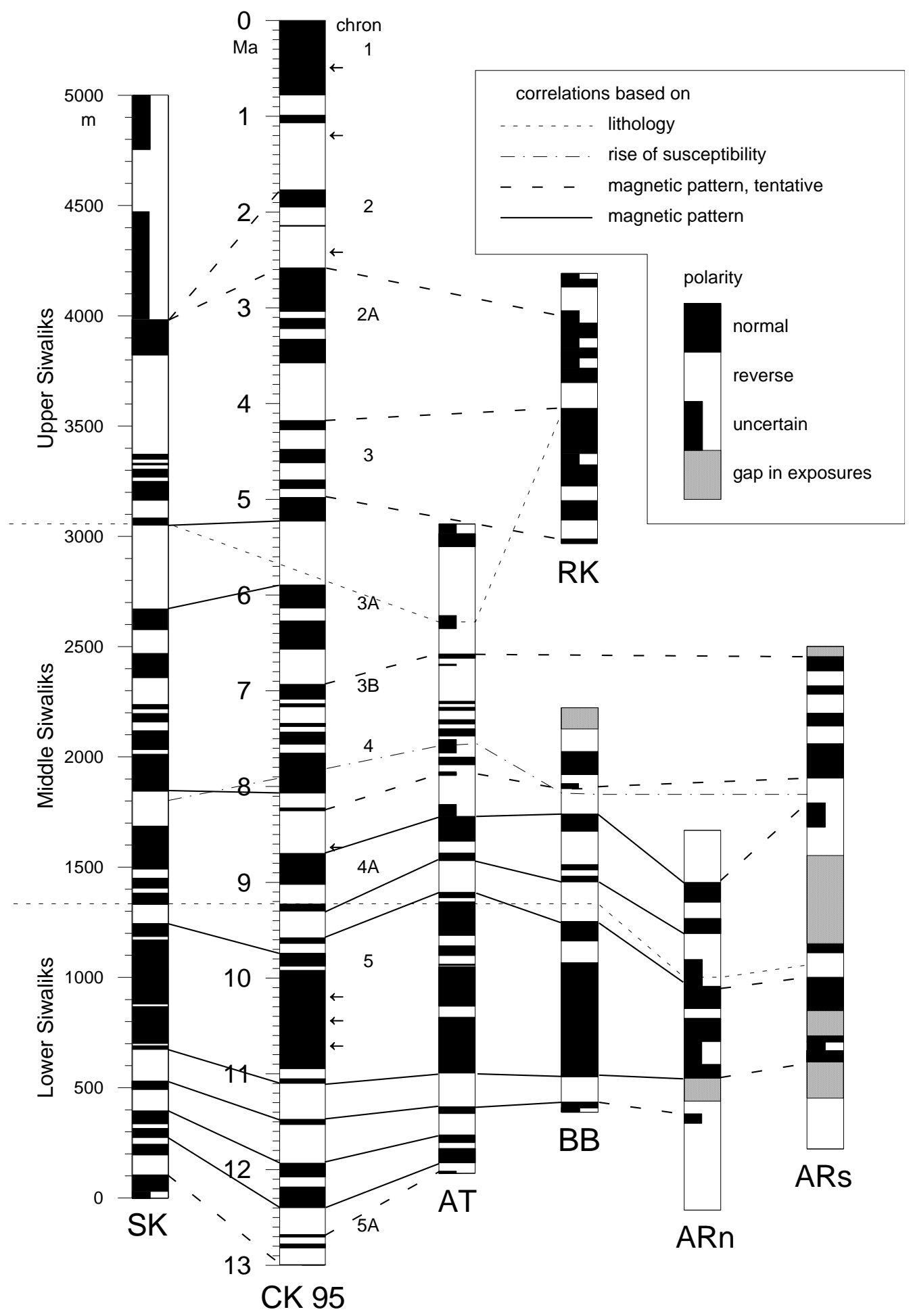

Figure 7. Correlation of polarity sequences for the Surai Khola - Amiliya-Tui (SK-AT) area. All sections have the same thickness scale. The sections covered are: AT: Amiliya-Tui, ARn: Arjun Khola north, ARs: Arjun Khola south, BB: Bhalubang, and SK: Surai Khola, all shown in Fig. 5a. The lower ends of the sections are placed in such a way that the first lithological boundary common to the two adjacent sections falls roughly at the same level. CK95 denotes the geomagnetic polarity scale by Cande \& Kent (1995) used as a standard (modified after Rösler et al., 1997). The arrows besides the CK95 scale indicate the levels corresponding to the middle of the cryptochrons. 


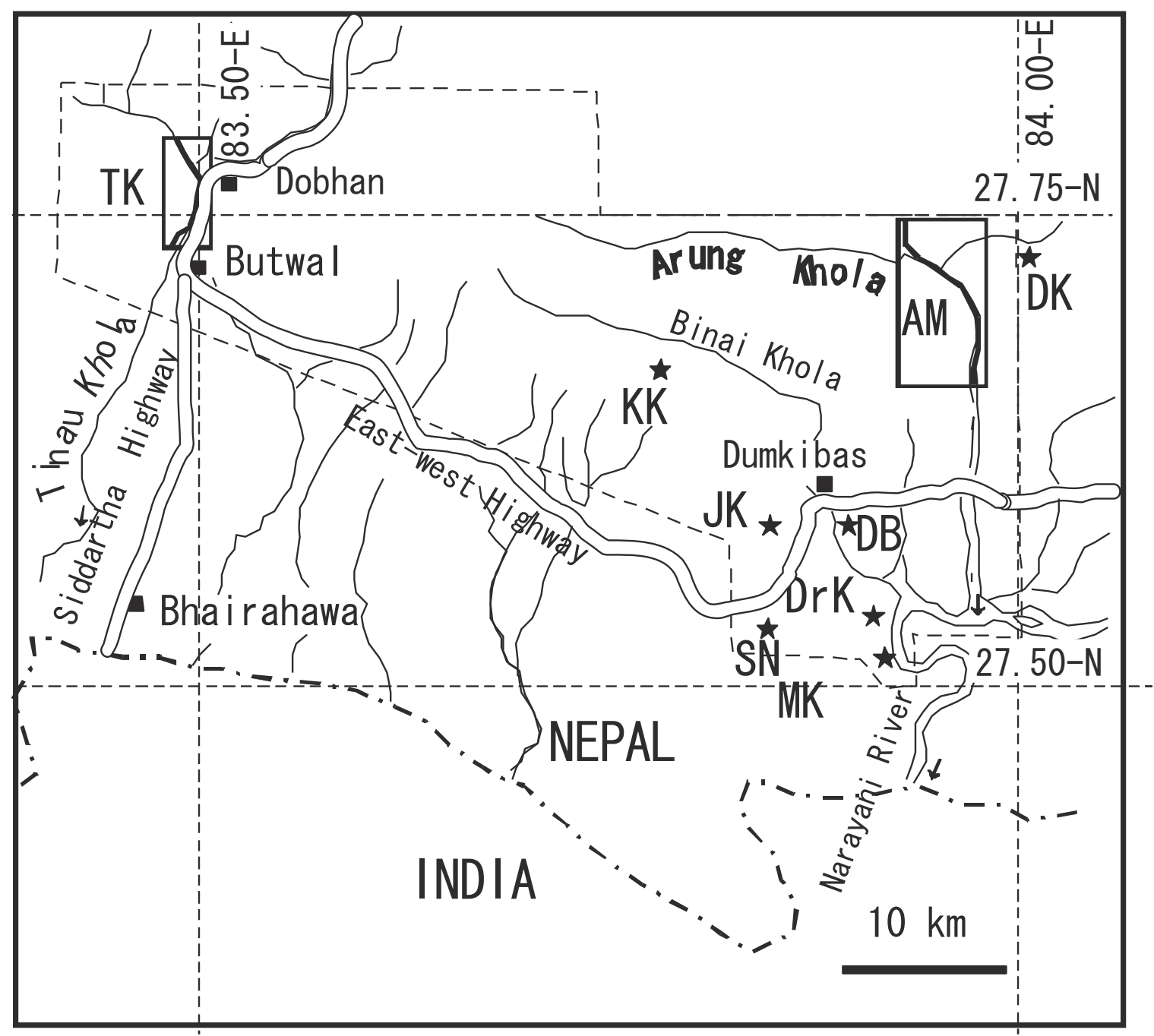

Figure 8. Sketch map (modified after Tokuoka et al., 1990) of Arung Khola -Tinau Khola (AK-TK) area with locations of the individual sections. The irregular polygon covers area mapped in detail by Tokuoka's team. Tinau Khola (TK) section and Arung Khola-Murali Khola (AM) sections are shown by rectangular frames. For the other abbreviated sections shown by stars refer to the caption of Fig. 9. 


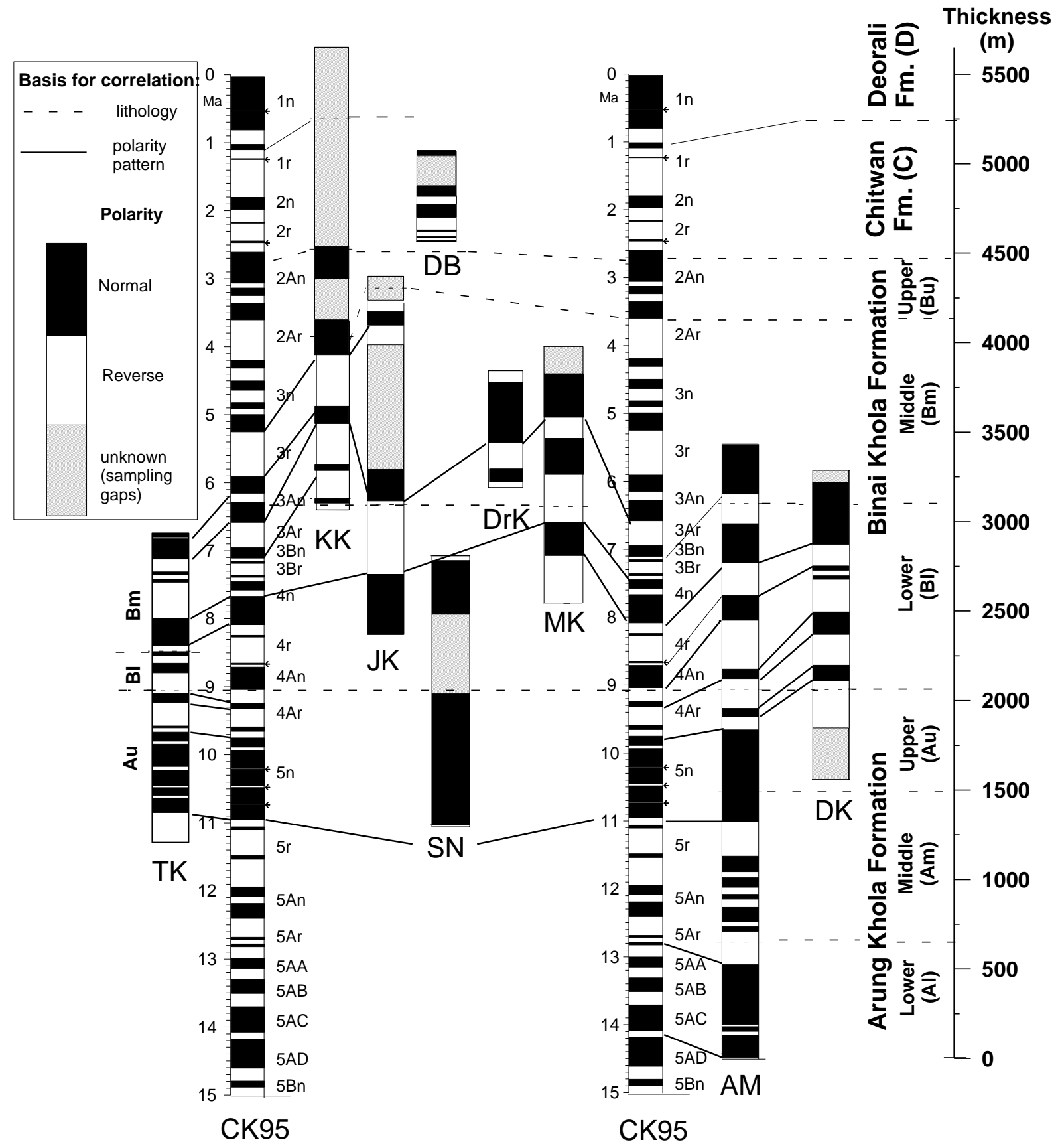

Figure 9. Correlation of polarity sequences for the Arung Khola - Tinau Khola area (AK-TK) with the standard geomagnetic polarity scale (CK95). All sections are plotted in the same scale. TK: Tinau Khola, KK: Kusaundi Khola, JK: Jimuri Khola, DB: Dumkibas, SN: Satbudn Nala, DrK: Darsing Khola, MK: Madari Khola, AM: Arung Khola-Murali Khola, and DK: Dang Khola. Polarity sequence for TK section is taken from Gautam \& Appel (1994). Other sections are those selected from Tokuoka et al. (1986). Lithostratigraphy is after Tokuoka et al. (1986; 1990). 


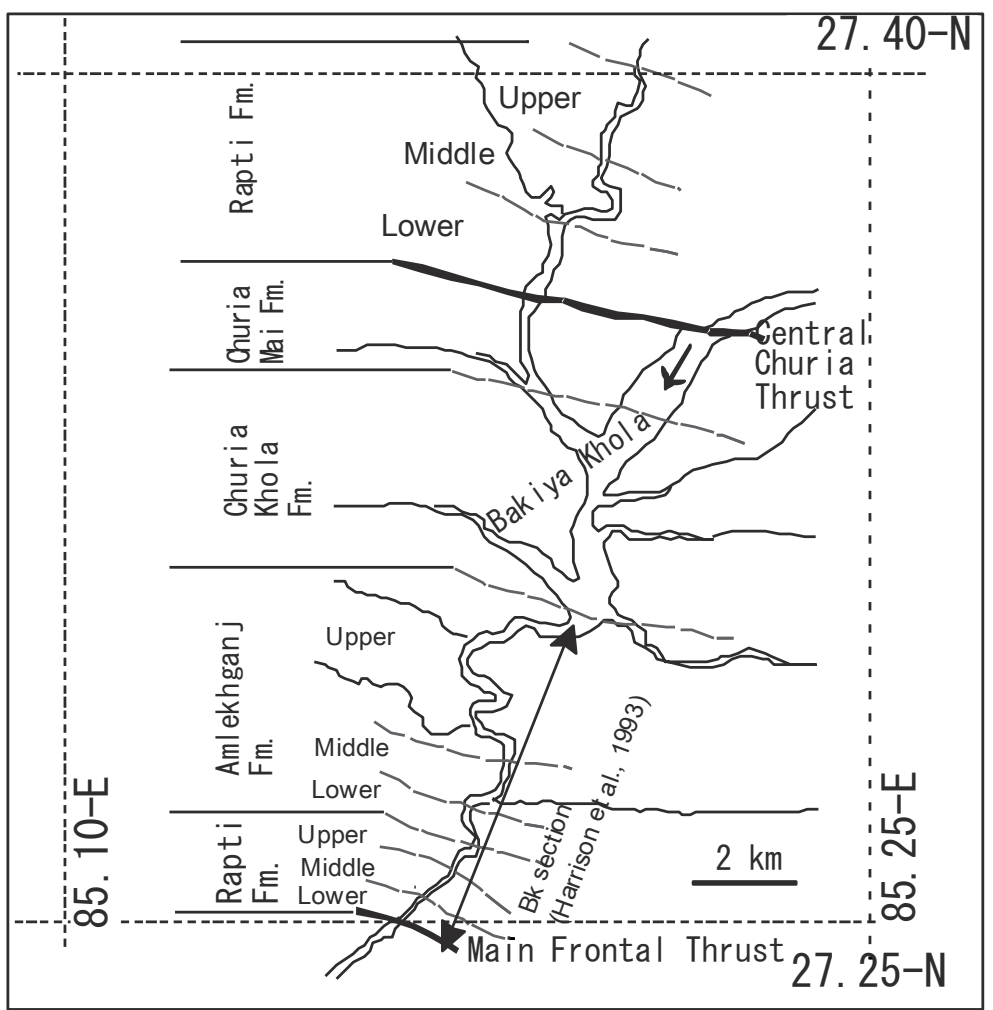

Figure 10. Location map of the Bakiya Khola (BK) section. Note the inferred position of the Bakiya Khola section measured by Harrison et al. (1993) presented in Fig. 12. Geological information included is after Ulak and Nakayama (1998; see also Fig. 2 for formation details).

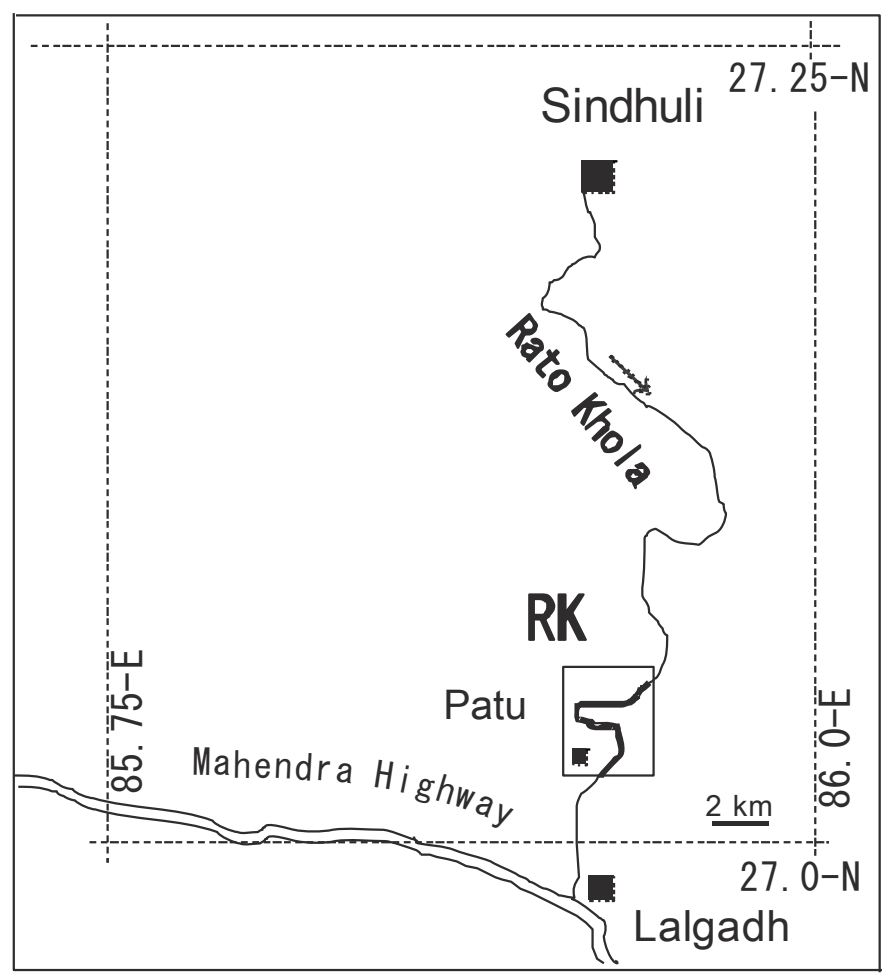

Figure 11. Location map of the Rato Khola (RK) section. 


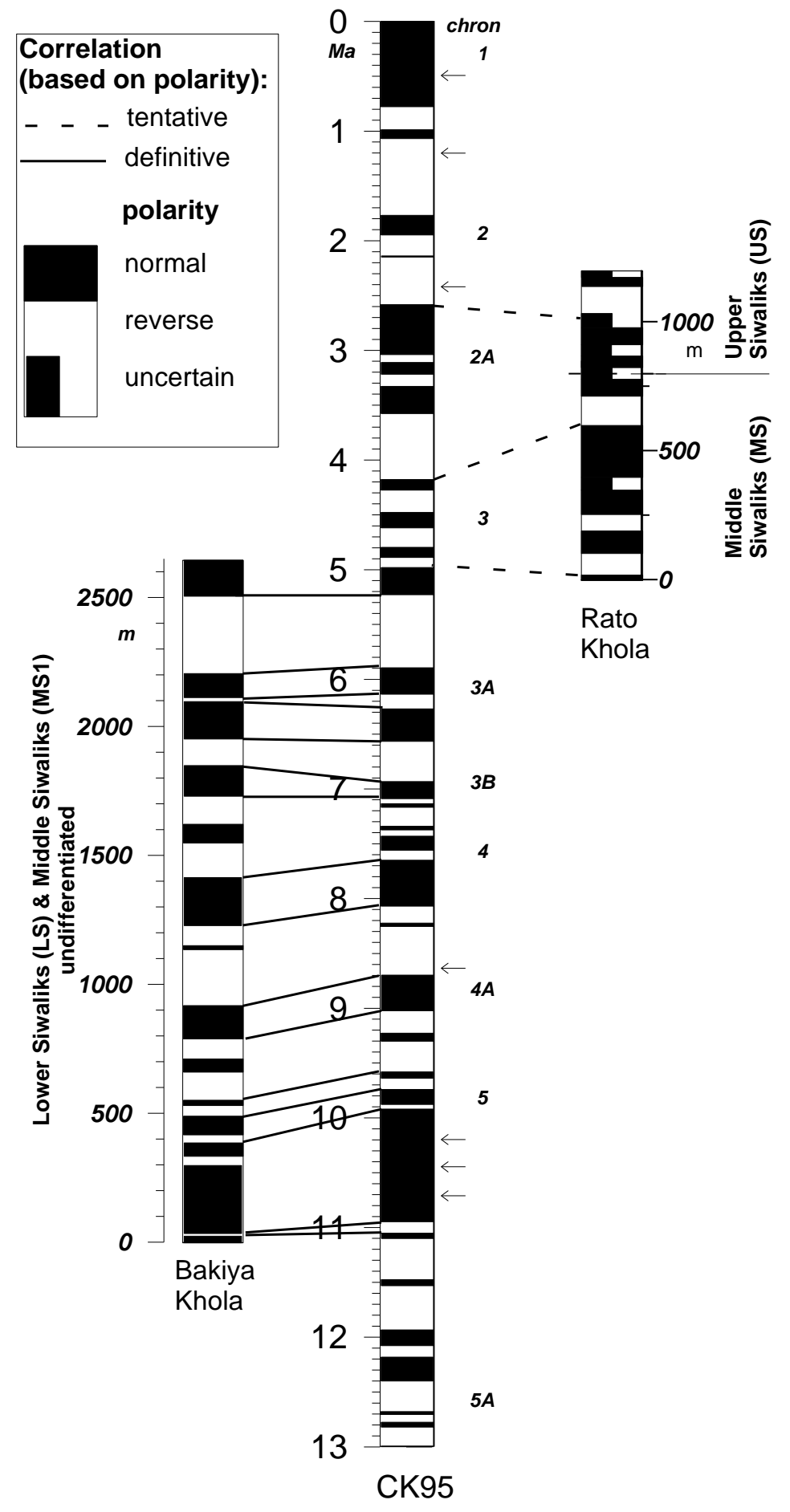

Figure 12. Correlation of the polarity sequences derived from the portions of Bakiya Khola and Rato Khola (Harrison et al. 1983 and Rösler et al. 1997, respectively) and their correlation with GPTS (CK95). 


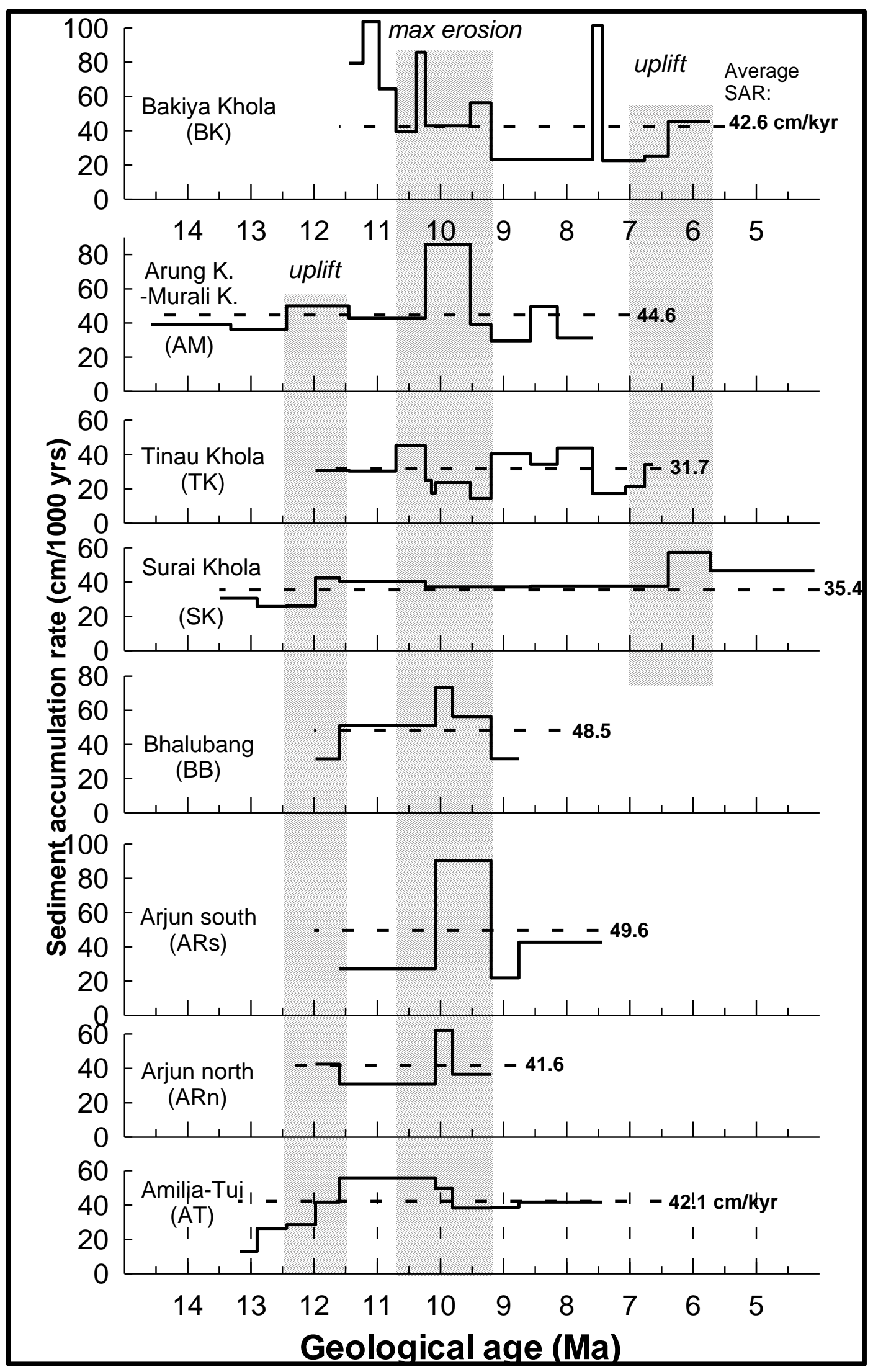

Figure 13. Sediment accumulation rates (SARs) for sections with reasonable thickness estimates and welldefined magnetic polarity stratigraphy. Average SAR for each section is indicated by dotted horizontal line and number given at the right end. Hatched areas indicate the inferred periods of rapid uplift/erosion of the Himalayan source area. 


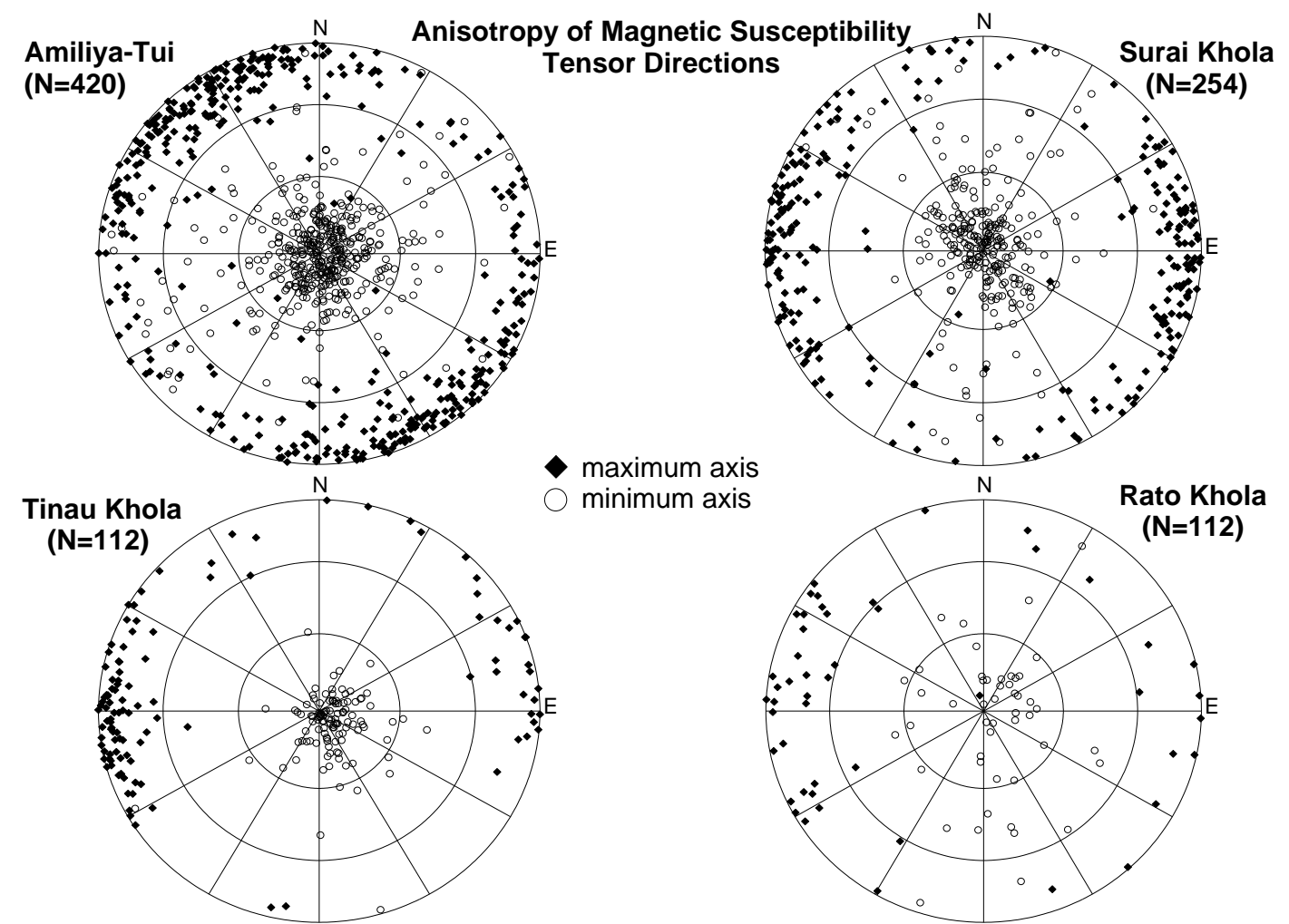

Figure 14. Comparison of the maximum and minimum axes of the anisotropy of magnetic susceptibility $\left(\mathrm{k}_{\max }\right.$ and $\mathrm{k}_{\mathrm{min}}$ ) for four sections indicated (Schimdt's equal-area projection, lower hemisphere and directions corrected for the bedding tilt).
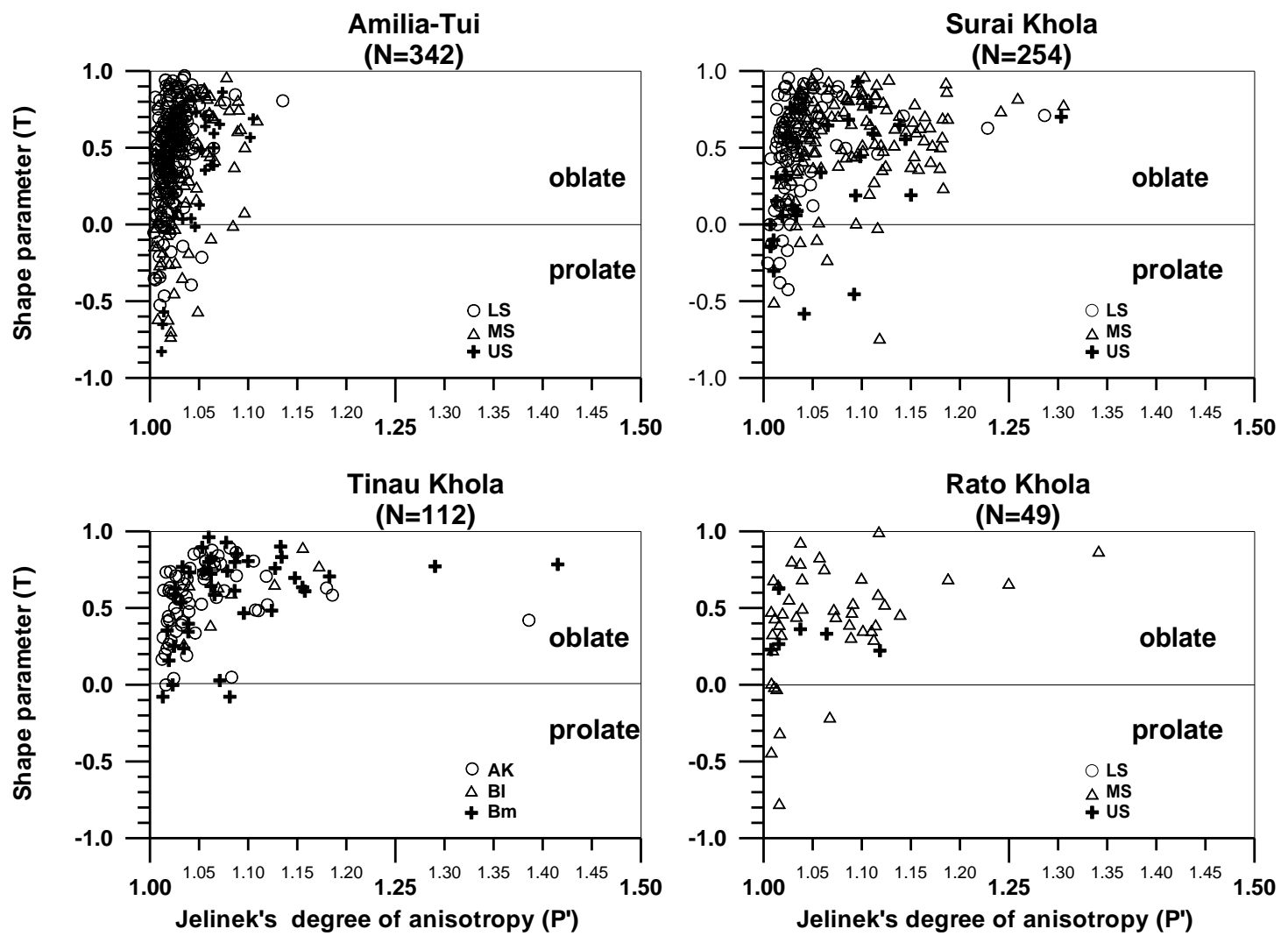

Figure 15. Relationship between the susceptibility ellipsoid shape $(\mathrm{T})$ and the degree of anisotropy (P') in the four Siwalik sections of central Nepal. 